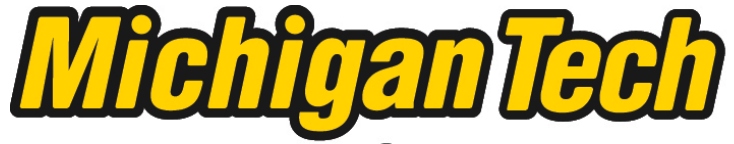 \\ Michigan Technological University Create the Future Digital Commons @ Michigan Tech
}

Dissertations, Master's Theses and Master's Reports - Open

Dissertations, Master's Theses and Master's

Reports

2014

\section{HOUSEHOLD SOLAR POWER SYSTEM}

He Jiang

Michigan Technological University

Follow this and additional works at: https://digitalcommons.mtu.edu/etds

Part of the Power and Energy Commons

Copyright 2014 He Jiang

\section{Recommended Citation}

Jiang, He, "HOUSEHOLD SOLAR POWER SYSTEM", Master's report, Michigan Technological University, 2014.

https://doi.org/10.37099/mtu.dc.etds/827

Follow this and additional works at: https://digitalcommons.mtu.edu/etds

Part of the Power and Energy Commons 


\title{
HOUSEHOLD SOLAR POWER SYSTEM
}

\section{By}

He Jiang

\begin{abstract}
A REPORT
Submitted in partial fulfillment of the requirements for the degree of MASTER OF SCIENCE

In Electrical Engineering
\end{abstract}

MICHIGAN TECHNOLOGICAL UNIVERSITY

2014

(C) 2014 He Jiang 
This report has been approved in partial fulfillment of the requirements for the Degree of MASTER OF SCIENCE in Electrical Engineering.

Department of Electrical and Computer Engineering

Report Advisor: $\quad$ Lucia Gauchia

Committee Member: Chee-Wooi Ten

Committee Member: Ye Sun

Department Chair: Daniel Fuhrmann 
Abstract-Photovoltaic power has become one of the most popular research area in new energy field. In this report, the case of household solar power system is presented. Based on the Matlab environment, the simulation is built by using Simulink and Simpowersystem. There are four parts in a household solar system, solar cell, MPPT system, battery and power consumer. Solar cell and MPPT system are been studied and analyzed individually. The system with MPPT generates 30\% more energy than the system without MPPT. After simulating the household system, it is can be seen that the power which generated by the system is $40.392 \mathrm{kWh}$ per sunny day. By combining the power generated by the system and the price of the electric power, $\mathbf{8 . 4 2}$ years are need for the system to achieve a balance of income and expenditure when weather condition is considered. 


\section{Table of Contents}

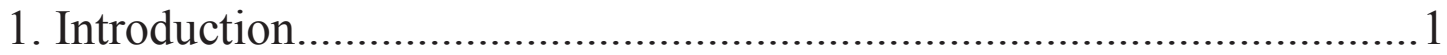

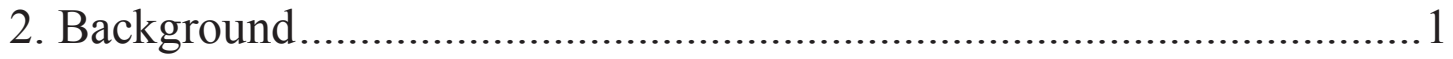

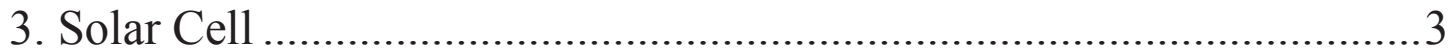

3.1 The Basic Concept of Solar Cell ................................................. 3

3.2 The Equivalent Circuit of Solar Cell ............................................ 3

3.3 The Output Characteristics of Solar Cell....................................... 4

3.4 The Mathematical Model of Solar Cell for Engineering Application

3.5 The Model of Solar Cell Considering Solar Radiation and

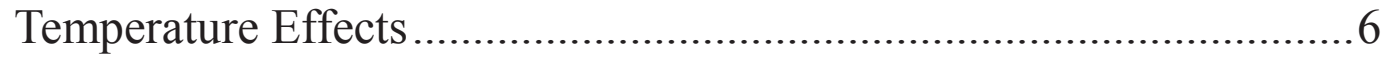

3.6 The Simulation Model of Solar Cell …........................................ 7

4. Maximum Power Point Tracking System.............................................12

4.1 The Basic Concepts and Principles of MPPT System..................13

4.2 The Algorithm of Maximum Power Point Tracking .................... 14

4.3 The Control Method of Maximum Power Point Tracking System18

4.4 The Simulation Model of Maximum Power Point Tracking System

5. The Simulation of Household Solar Power System with Maximum 
Power Point Tracking

5.1 The Simulation Model of the System ........................................23

5.2 The Parameter Settings of the Simulation ...................................24

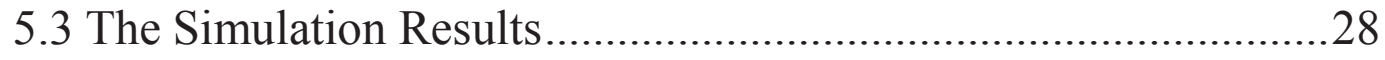

6. The Economic Effects of the Solar System ..........................................31

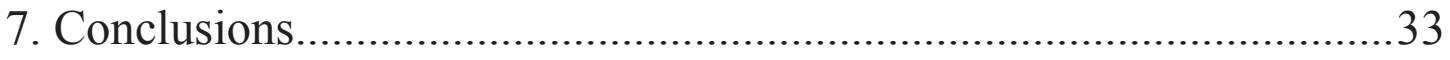

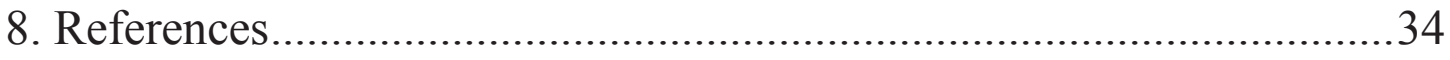

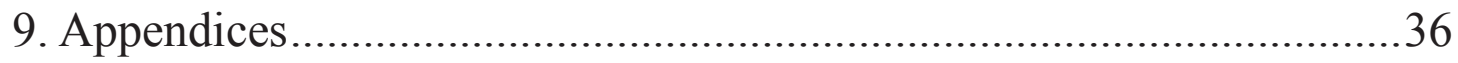




\section{Introduction}

The depletion of fossil fuel reserves is a growing concern in terms of energy sustainability. So now the whole world is paying attention to renewable energy, hoping this kind of energy can change the energy structure of the society, supporting long-term sustainable development. Solar power became widely favored due to its safety, reliability, noiseless, non-pollution and low maintenance costs. Not only it can provide electric power house by house separately, but also can supply power centralized.

\section{Background}

The household solar system is the most widely used solar system nowadays. A large number of families in USA choose to upgrade their houses with a solar system, especially in California and Texas.

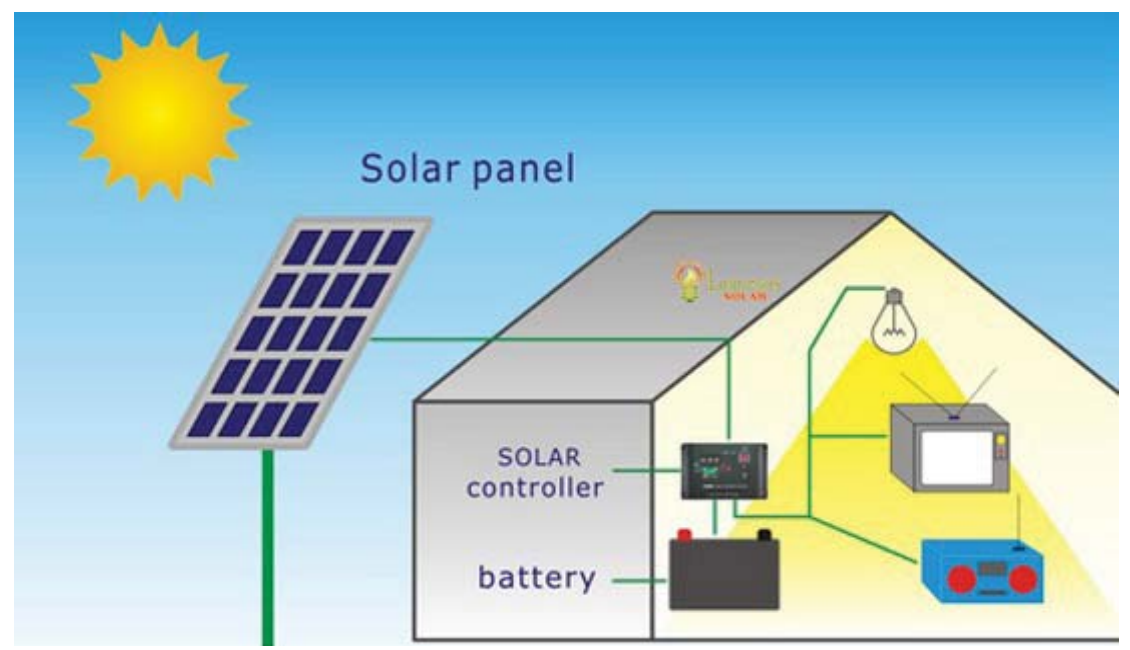

Figure 1: Household Solar System [8] 
There are four main parts in a household solar system which are showed in Figure 1. The first part is a solar panel that generates electric power by absorbing solar radiation. The second part is a solar controller (DC-DC converter) which can change the working status of the solar panel, and make sure the solar panel is working at maximum power point. The third part is a battery that can store electric energy while the solar panel generates more power than the load need, and providing power to the load during night time or raining days. The last part is the electric power consumer (load).

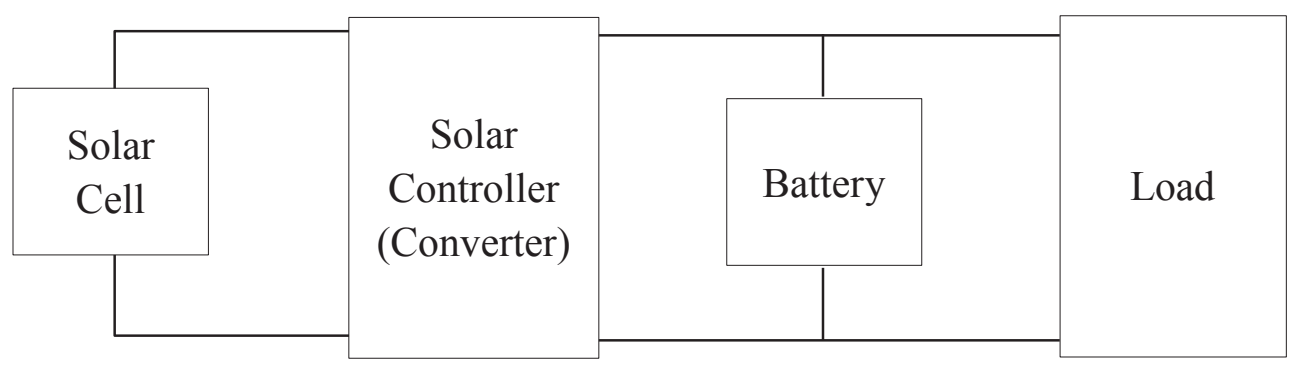

Figure 2: The Typical Structure of Photovoltaic System

The typical structure of a household solar system which shows in Figure 2 tells the basic logical relationships between the four main parts of the solar system. By simulating the whole system in Matlab, the power that generated by the system can be obtained. To this effect, this project will size and simulate a solar-battery system for a household in Houston (Texas). Local information regarding weather and electricity price will be included. 


\section{Solar Cell}

\subsection{The Basic Concept of Solar Cell}

A solar cell is an electrical device that converts the energy of light directly into electricity by the photovoltaic effect [9]. Photocurrent is produced inside of the solar cell when the sunlight irradiates on the solar cell. Therefore, voltage and current can be obtained at the terminal of the solar cell.

\subsection{The Equivalent Circuit of Solar Cell}

Figure 3 shows the single diode equivalent circuit of a solar cell. The photocurrent of a solar cell which is under a constant radiation won't change. In the model $I_{L}$ can be considered as a constant current source.

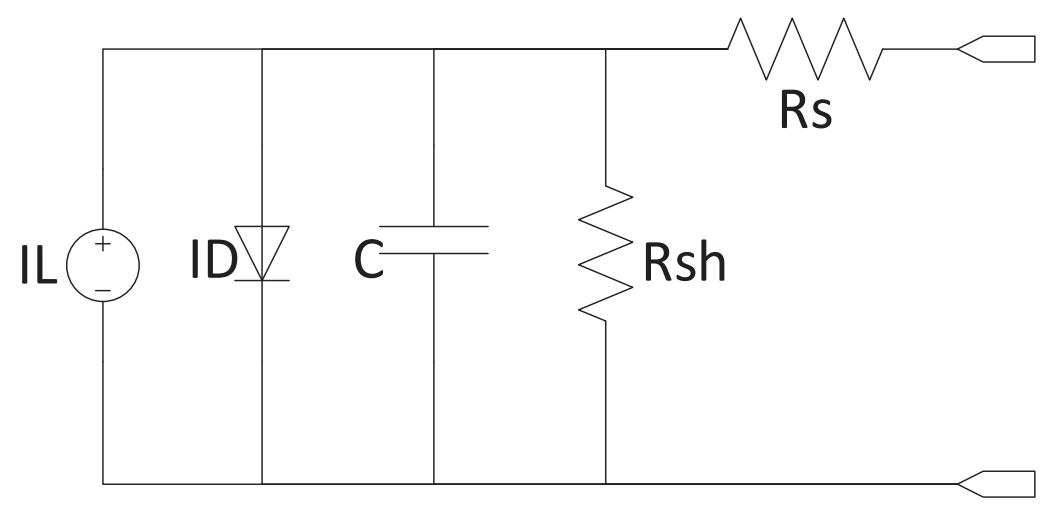

Figure 3: The Single Diode Equivalent Circuit of Solar Cell

Normally, $C$ only has a very small effect on $I$, so $C$ can be ignored. So the I-V equation of a solar cell can be shown as:

$$
\mathrm{I}=\mathrm{I}_{\mathrm{L}}-\mathrm{I}_{0}\left\{\exp \left[\frac{\mathrm{q}\left(\mathrm{U}+\mathrm{IR}_{\mathrm{S}}\right)}{\mathrm{AkT}_{\mathrm{c}}}\right]-1\right\}-\frac{\mathrm{U}+\mathrm{IR}_{\mathrm{S}}}{\mathrm{R}_{\mathrm{sh}}}
$$


In the equation (1): $I_{0}$ is the reverse saturation current of the diode; $T_{c}$ is the temperature of the solar cell; $A$ is the factor of diode.

\subsection{The Output Characteristics of Solar Cell}

The output I-V characteristic of a solar cell is one of the most important technical data to analyze a solar cell system. It cannot be represented by linear equation. Therefore, nonlinear fitting methods are used to solve this problem. But these methods require a large number of actual measured data as a basis, and the model is very complex. Exponential model only needs four parameters under standard test conditions. By using these four parameters which are $I_{m}$ (the current when the solar cell operates at max power point) $U_{m}$ (the voltage when the solar cell operates at max power point) $I_{s c}$ (the short current of the solar cell) and $U_{o c}$ (the open circuit voltage of the solar cell) the parameters of the model can be obtained. According to the single diode equivalent circuit model of a solar cell and the basic analytical expression of the output current and voltage of a solar cell, a simplified single-exponential model of a solar cell can be obtained.

\subsection{The Mathematical Model of Solar Cell for Engineering}

\section{Application}

The most important characteristic of a mathematical model which is for engineering application is a combination of practicality and accuracy. Engineering application model of solar cell is usually requires to be able to reproduce the behavior of a solar 
cell by using several technical parameters provided by the supplier, for instance, $I_{s c}$, $U_{o c}, I_{m}, U_{m}$ and $P_{m}$.

In this way, the computer can analyze the model easily.

Based on equation (1) and two approximations, which are:

1) Ignore item $\frac{U+I R_{S}}{R_{S h}}$ because normally $R_{S h}$ is large, so $\frac{U+I R_{S}}{R_{S h}}$ is very small and almost has no effect on the light current.

2) Assume $I_{L}$ equal to $I_{s c}$, because $R_{S}$ is far smaller than diode forward resistance in normal conditions.

When the solar cell is working at open circuit situation $\left(I=0, \mathrm{U}=U_{o c}\right)$, the $\mathrm{I}-\mathrm{V}$ equation of a solar cell can be simplified as:

$$
I=I_{s c}\left(1-C_{1}\left\{\exp \left[U /\left(C_{2} U_{o c}\right)\right]-1\right\}\right)
$$

When the solar cell is working at maximum power point situation $\left(\mathrm{I}=I_{m}, \mathrm{U}=U_{m}\right)$, the I-V equation of a solar cell can be simplified as:

$$
I_{m}=I_{s c}\left(1-C_{1}\left\{\exp \left[U_{m} /\left(C_{2} U_{o c}\right)\right]-1\right\}\right)
$$

Considering in normal temperature condition $\exp \left[U_{m} / C_{2} U_{o c} \gg 1\right.$, so the item "-1" in equation (3) can be ignored and $C_{1}$ can be solved.

$$
C_{1}=\left(1-I_{m} / I_{s c}\right) \exp \left[-U_{m} /\left(C_{2} U_{o c}\right)\right]
$$

When the solar cells working at open circuit condition $\left(\mathrm{I}=0, \mathrm{U}=U_{\text {oc }}\right)$, and bring equation (4) into (2) can obtain:

$$
0=I_{s c}\left\{1-\left(1-I_{m} / I_{s c}\right) \exp \left[-U_{m} /\left(C_{2} U_{o c}\right)\right] *\left[\exp \left(1 / C_{2}\right)-1\right]\right.
$$

The item "-1" can be ignored because of $\exp \left(1 / C_{2}\right) \gg 1$. 
After ignoring "-1", $C_{2}$ can be solved:

$$
C_{2}=\left(U_{m} / U_{o c}-1\right)\left[\operatorname{In}\left(1-I_{m} / I_{s c}\right)\right]^{-1}
$$

Therefore, according to equation (4) and (6), $C_{1}$ and $C_{2}$ can be obtained by using $I_{s c}$, $U_{o c}, I_{m}, U_{m}$ which are all normal technical parameters of a solar cell. The output I-V characteristic of a solar cell can be solved by using equation (2).

\subsection{The Model of Solar Cell Considering Solar Radiation and}

\section{Temperature Effects}

The output I-V characteristic curve of solar is related to the solar radiation and the temperature of the solar panel. Normally, the intensity of solar radiation at surface is changing from $0 \mathrm{~W} / \mathrm{m}^{2}$ to $1200 \mathrm{~W} / \mathrm{m}^{2}$. The temperature of the solar cell can be large, from $-20{ }^{\circ} \mathrm{C}$ to $70{ }^{\circ} \mathrm{C}$. Normally $S_{r e f}=1000 \mathrm{~W} / \mathrm{m}^{2}, T_{r e f}=25^{\circ} \mathrm{C}$ is chosen as the reference solar radiation intensity and the reference temperature of the solar cell. The environmental influence on the solar cell must be considered, when the solar cell is not working at the reference solar radiation intensity and temperature conditions.

Assuming $I_{\text {scref }}, U_{\text {ocref }}, I_{m r e f}, U_{m r e f}$ are $I_{s c}, U_{o c}, I_{m}, U_{m}$, when the solar cell is working at reference condition and after fitting large number of experimental data, the following equations has proved qualified for engineering application.

$$
\begin{gathered}
\mathrm{I}_{\mathrm{sc}}=\mathrm{I}_{\text {scref }} \frac{\mathrm{s}}{\mathrm{S}_{\text {ref }}}\left[1+\mathrm{a}\left(\mathrm{T}_{\mathrm{c}}-\mathrm{T}_{\text {cref }}\right)\right] \\
\mathrm{U}_{\mathrm{oc}}=\mathrm{U}_{\text {ocref }}\left[1-\mathrm{c}\left(\mathrm{T}_{\mathrm{c}}-\mathrm{T}_{\text {cref }}\right)\right] \ln \left[\mathrm{e}+\mathrm{b}\left(\mathrm{S}-\mathrm{S}_{\text {ref }}\right)\right] \\
\mathrm{I}_{\mathrm{m}}=\mathrm{I}_{\text {mref }} \frac{\mathrm{s}}{\mathrm{S}_{\text {ref }}}\left[1+\mathrm{a}\left(\mathrm{T}_{\mathrm{c}}-\mathrm{T}_{\text {cref }}\right)\right]
\end{gathered}
$$




$$
\mathrm{U}_{\mathrm{m}}=\mathrm{U}_{\mathrm{mref}}\left[1-\mathrm{c}\left(\mathrm{T}_{\mathrm{c}}-\mathrm{T}_{\mathrm{cref}}\right)\right] \ln \left[\mathrm{e}+\mathrm{b}\left(\mathrm{S}-\mathrm{S}_{\mathrm{ref}}\right)\right]
$$

From (7) to (10): $a, b, c$ are compensation coefficient, all constant. $a=$ $0.0025^{\circ} \mathrm{C}^{-1}, b=0.0005\left(W / m^{2}\right)^{-1}, c=0.00288^{\circ} \mathrm{C}^{-1}$.

According to $I_{\text {scref }}, U_{\text {ocref }}, I_{m r e f}, U_{m r e f}$ which are parameters of solar cell under reference radiation level and reference temperature, by using related compensation coefficient $I_{s c}, U_{o c}, I_{m}, U_{m}$ which are parameters of solar cell, the new radiation level and temperature can be obtained. After solving $I_{s c}, U_{o c}, I_{m}, U_{m}$ at new solar radiation intensity and temperature condition, the engineering application model of solar cell can be obtained by using equation (6), (4) and (2).

\subsection{The Simulation Model of Solar Cell}

After obtaining equations (2), (4), (6), (7), (8), (9) and (10), the model of solar cell can be implemented in Matlab by using Simulink blocks.

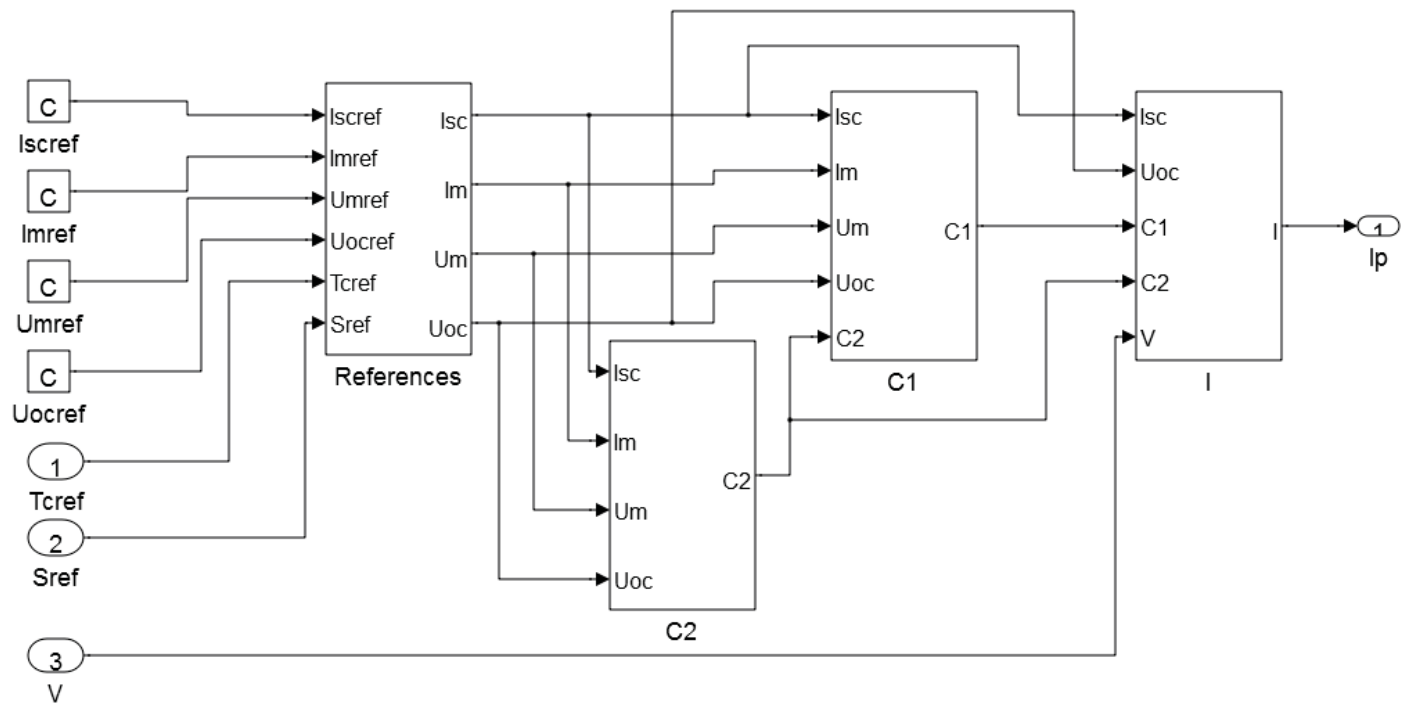

Figure 4: The Simulation Model of Solar Cell 
The model of solar cell is shown in Figure 4. By changing input $S$ and $T_{c}$, the model can simulate the I-V characteristic under different solar radiations and temperatures. If it is a new solar cell $I_{\text {scref }}, U_{\text {ocref }}, I_{\text {mref }}$ and $U_{\text {mref }}$ are needed to set up the simulation.

The simulation results when the solar panel working at reference condition is shown in Figure 5 and Figure 6 . In this simulation, it is assumed the following values: $I_{S C}=$ $0.65 \mathrm{~A}, U_{o c}=21.5 \mathrm{~V}, I_{m}=0.56 \mathrm{~A}, U_{m}=18 \mathrm{~V}$.

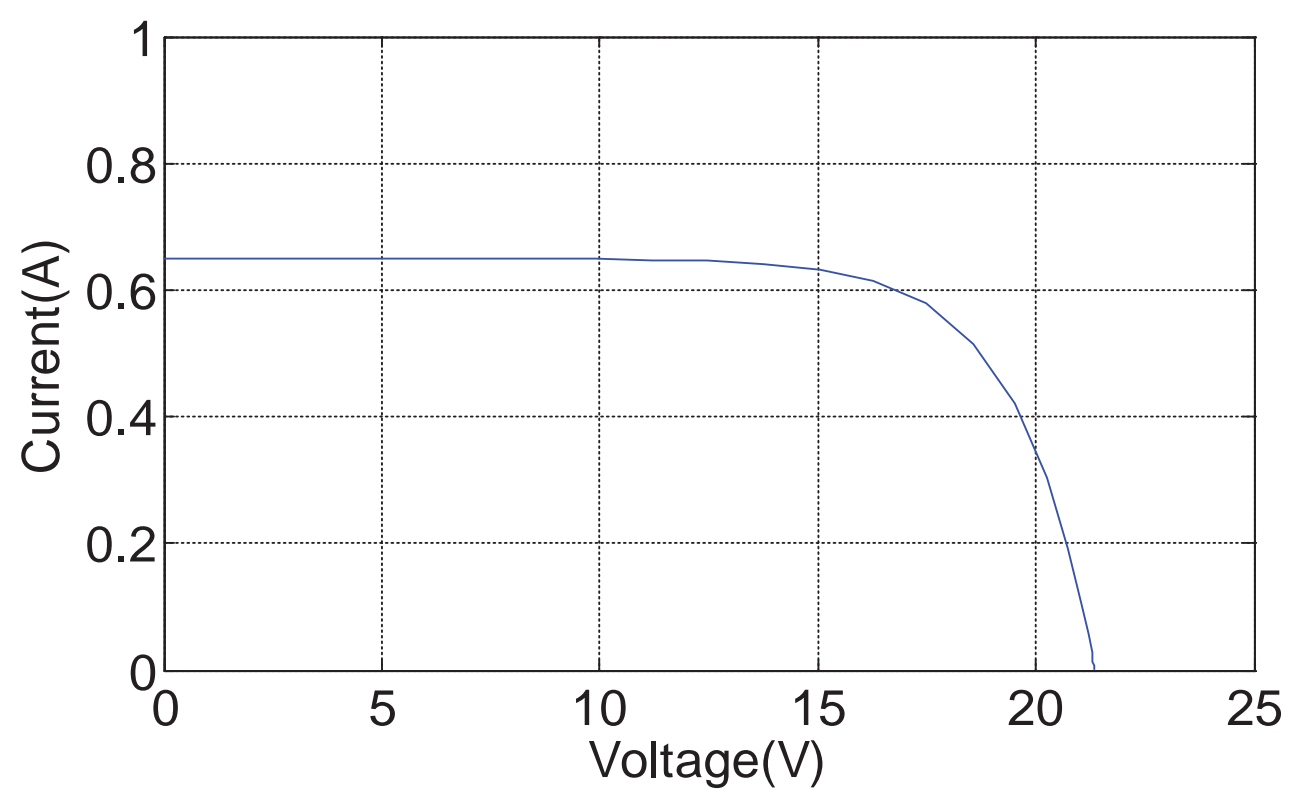

Figure5: I-V Characteristic Curve 


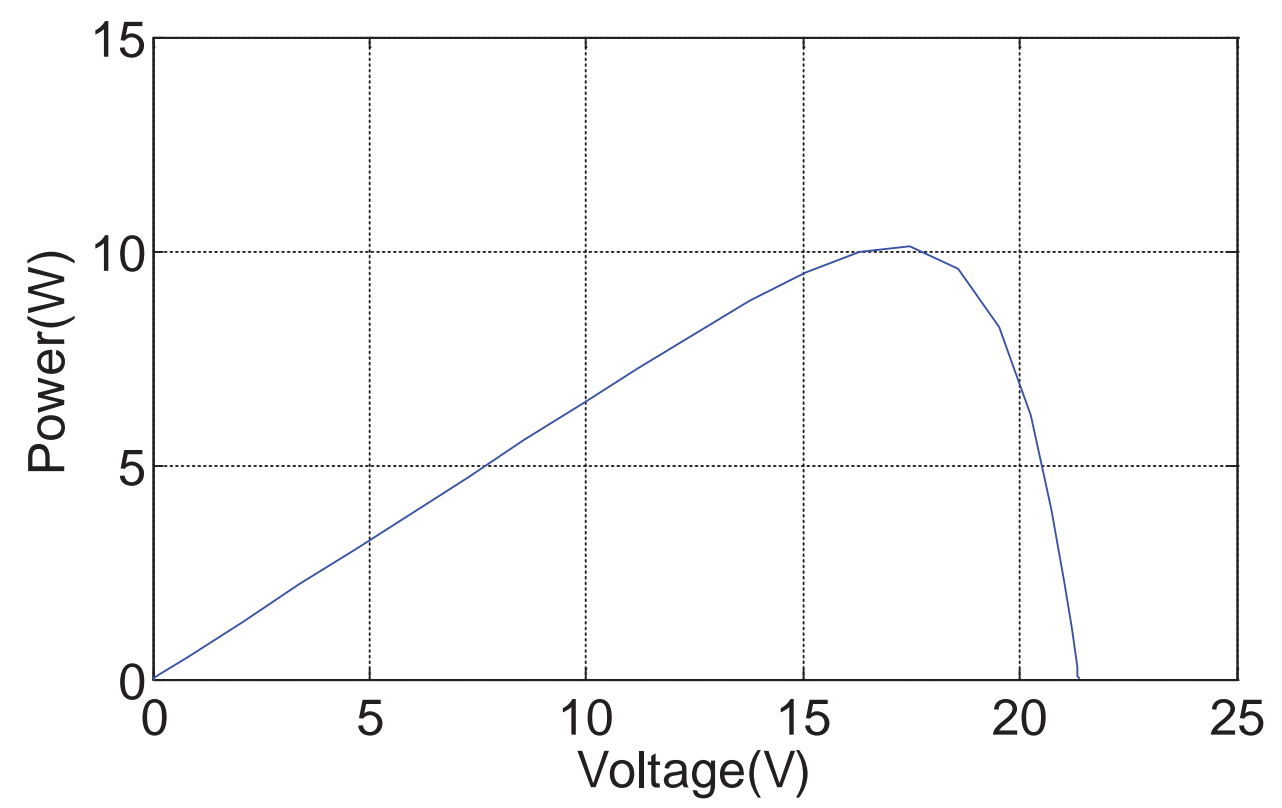

Figure6: P-V Characteristic Curve

When the solar radiation varies from $600 \mathrm{~W} / \mathrm{m}^{2}$ to $900 \mathrm{~W} / \mathrm{m}^{2}\left(100 \mathrm{~W} / \mathrm{m}^{2}\right.$ a step) and the temperature is kept constant $\left(T=25^{\circ} \mathrm{C}\right)$, the change of the $\mathrm{I}-\mathrm{V}$ characteristic curve is shown in Figure 7.

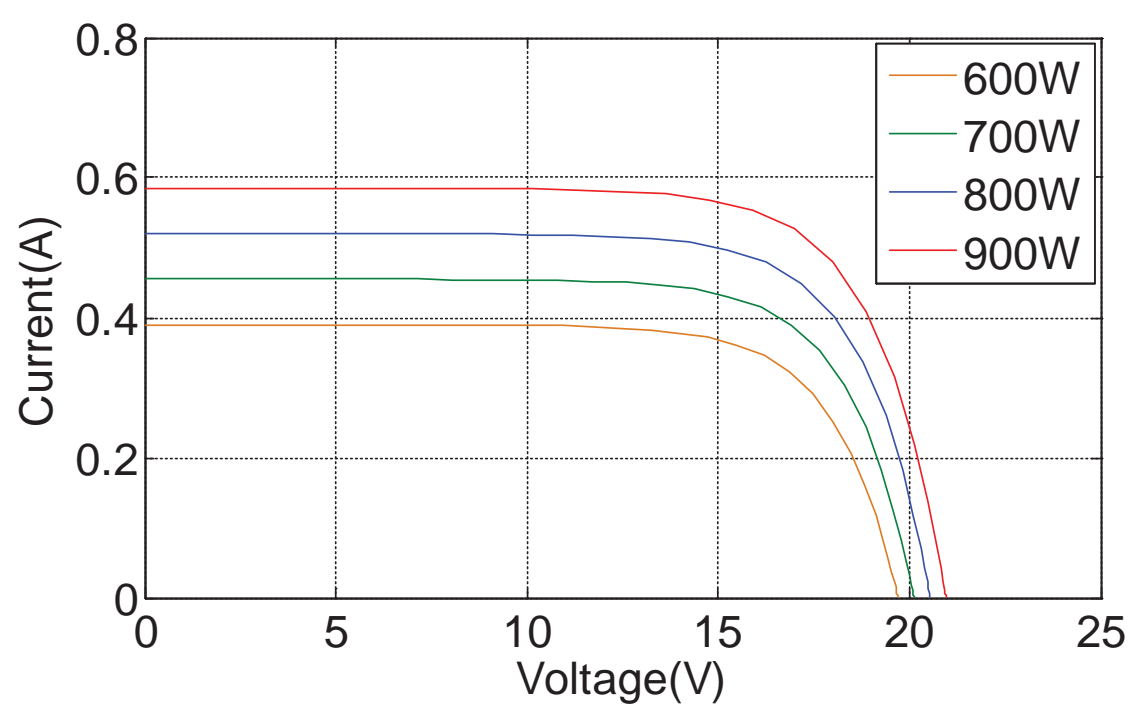

Figure 7: I-V Characteristic Curve under Same Temperature Different Solar Radiation Condition 
When the solar radiation varies from $600 \mathrm{~W} / \mathrm{m}^{2}$ to $900 \mathrm{~W} / \mathrm{m}^{2}\left(100 \mathrm{~W} / \mathrm{m}^{2}\right.$ a step) and the temperature is kept constant $\left(T=25^{\circ} \mathrm{C}\right)$, the change of the $\mathrm{P}-\mathrm{V}$ characteristic curve is shown in Figure 8.

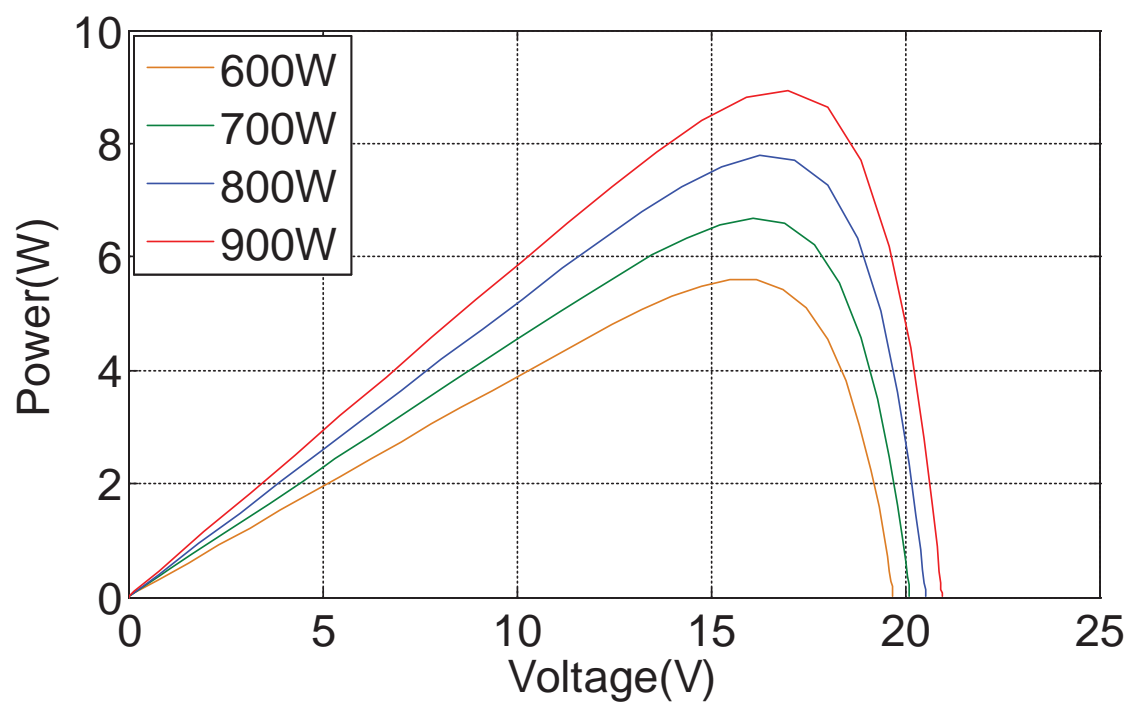

Figure 8: P-V Characteristic Curve under Same Temperature Different Solar Radiation Condition

When the temperature of the solar cell varies from $-20^{\circ} \mathrm{C}$ to $40^{\circ} \mathrm{C}\left(20^{\circ} \mathrm{C}\right.$ a step) and the solar radiation is kept constant $\left(\beta=1000 \mathrm{~W} / \mathrm{m}^{2}\right)$, the change of the I-V characteristic curve is shown in Figure 9. 


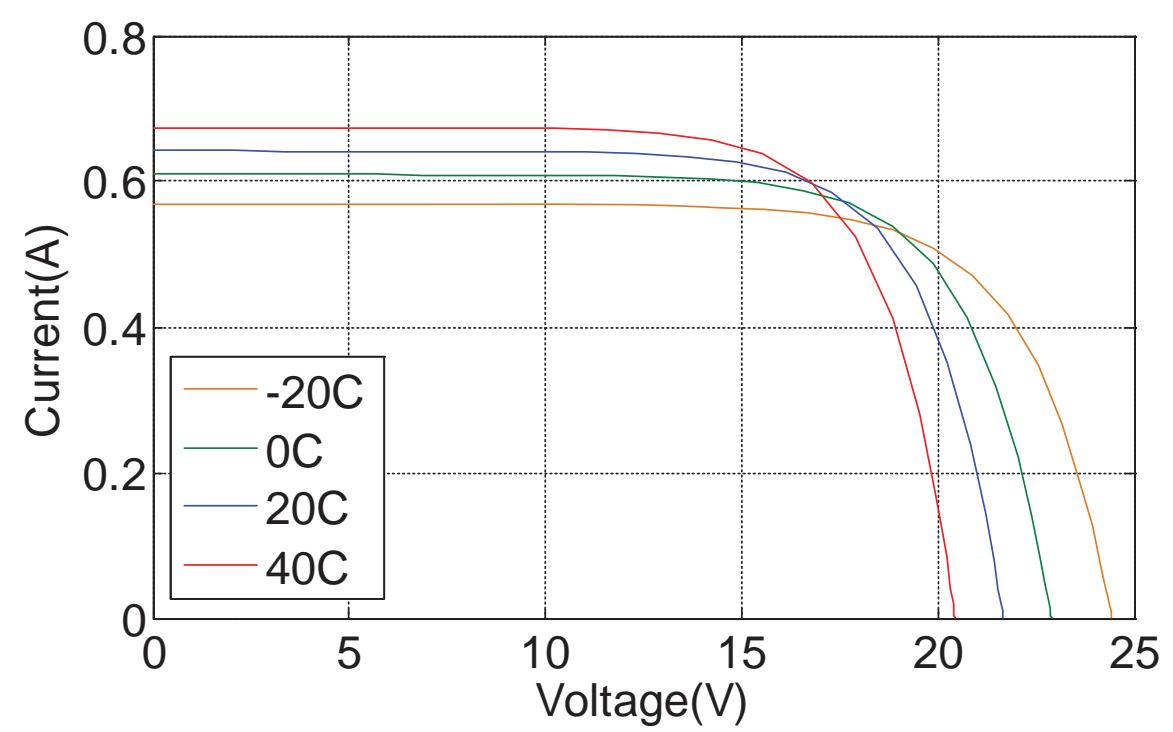

Figure 9: I-V Characteristic Curve under Same Solar Radiation Different Temperature Condition When the temperature of the solar cell varies from $-20^{\circ} \mathrm{C}$ to $40^{\circ} \mathrm{C}\left(20^{\circ} \mathrm{C}\right.$ a step $)$ and the solar radiation is kept constant $\left(\beta=1000 \mathrm{~W} / \mathrm{m}^{2}\right)$, the change of the $\mathrm{P}-\mathrm{V}$ characteristic curve is shown in Figure 10.

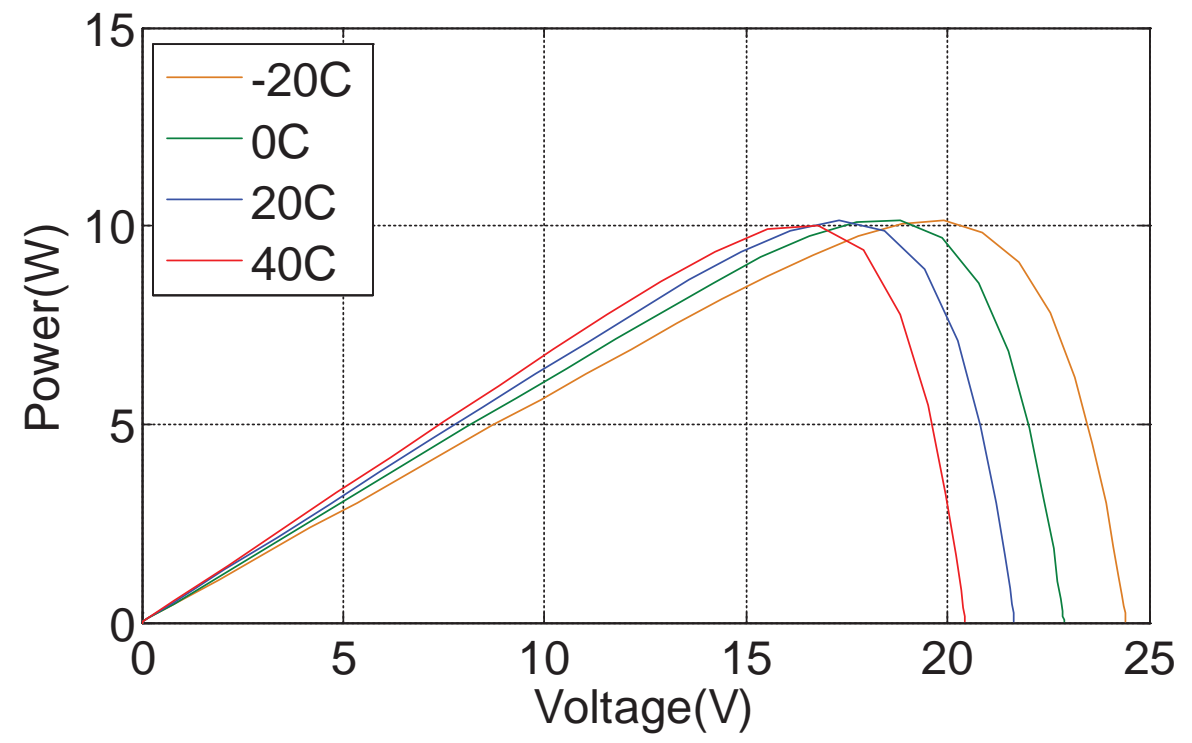

Figure 10: P-V Characteristic Curve under Same Solar Radiation Different Temperature Condition

From Figure 7 to Figure 10, the following essentials can be figured out: 
1) Solar radiation has a main effect on $I_{s c}$, temperature of the solar cell has a main effect on $U_{o c}$.

2) The output characteristic of the solar cell is approximately equal to a rectangle. The solar cell can be considered as a constant current source, when it is working at low output voltage. When the output voltage is near to open circuit voltage, the solar cell can be considered as a constant voltage source.

3) The output power can reach its maximum at a specific point which is the maximum power point of the solar cell. And it is changing by the effects of the outside environment.

4) Normally the maximum power point voltage is $80 \%$ of open circuit voltage.

\section{Maximum Power Point Tracking System (MPPT)}

The output power of a specific solar panel is related to two inputs: the solar radiation intensity and the temperature of the solar cell. At the outdoor environment, the solar radiation intensity and the temperature of the solar cell are changing all the time. It will cause the shift of the I-V and P-V output of the solar cell which will change the maximum power point position. Without MPPT, the solar power system may never operate at the maximum power point which will increase losses. 


\subsection{The Basic Concepts and Principles of MPPT System}

MPPT is the process of self-optimization of the solar cell. It will make a solar cell work at the maximum power point in any environment situation by controlling the output voltage of the solar cell. This report is using perturbation and observation [10] to track maximum power point, which is explained in the next section.

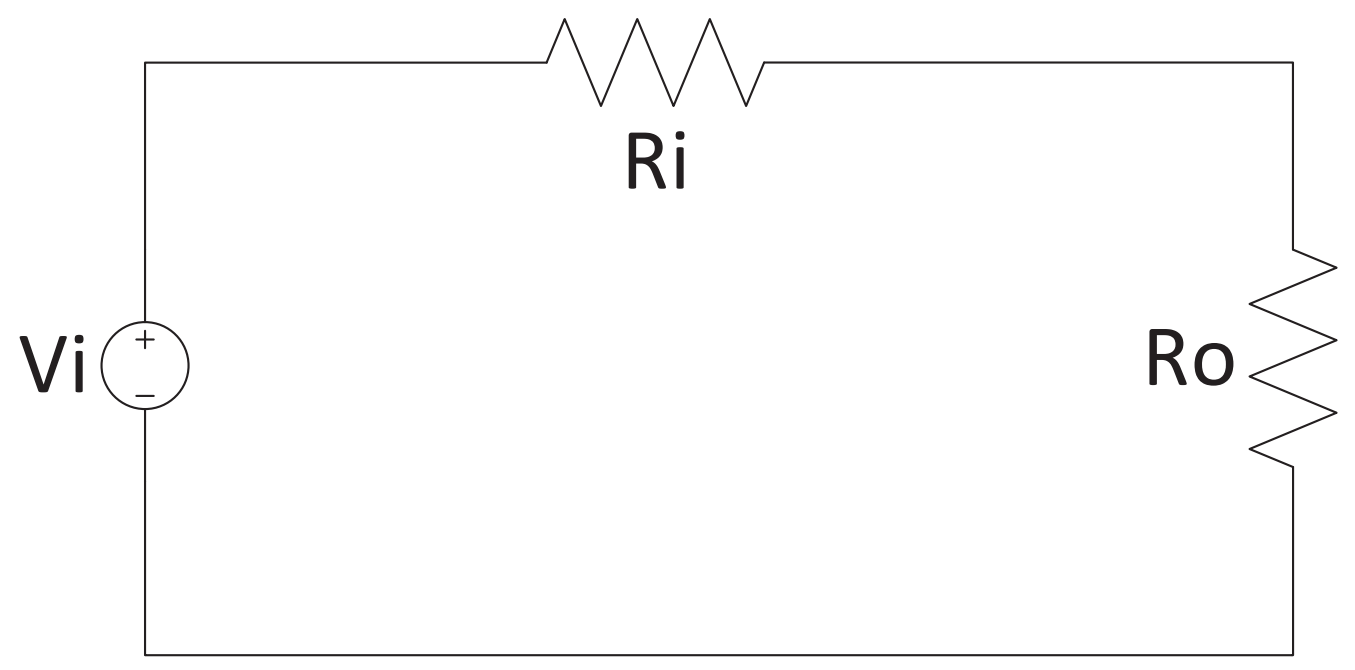

Figure 11: Linear System

Figure 11 shows the schematic of a linear system. $V_{i}$ is a voltage source. $R_{i}$ is the internal resistance of the source. $R_{o}$ is a load.

The power consumed by the load is:

$$
\mathrm{P}_{\mathrm{R}_{\mathrm{o}}}=\mathrm{I}^{2} \mathrm{R}_{\mathrm{o}}=\left(\frac{\mathrm{V}_{\mathrm{i}}}{\mathrm{R}_{\mathrm{i}}+\mathrm{R}_{\mathrm{o}}}\right)^{2} * \mathrm{R}_{\mathrm{o}}
$$

Equation (11) derivative with respect to $R_{o}$. We can get that:

$$
\frac{d P_{R_{0}}}{d R_{o}}=V_{i}^{2} \frac{R_{i}-R_{o}}{\left(R_{i}+R_{o}\right)^{3}}
$$

When $R_{o}=R_{i}, P_{R_{0}}$ reaches its maximum value. For a linear circuit system, when the resistance of the load equals to the internal resistance of the source, the maximum 
output power can be achieved. None of these circuits in the photovoltaic system is linear, but in a very short period the circuit in the photovoltaic system it can be considered as linear. So the basic idea is to change the equivalent resistance which is connected to the solar cell by using a DC-DC converter. And make this equivalent resistance equal to the internal resistance of the solar cell at any time, so that the maximum power point tracking can be achieved.

\subsection{The Algorithm of Maximum Power Point Tracking}

Perturbation and observation ( $\mathrm{P} \& \mathrm{O})$ is the most widely used MPPT algorithm nowadays. The basic idea is to change the output voltage of solar cell every short period; this process is called perturbation. As we know, if the output voltage of the solar cell has been changed, the output power of the solar will change with it. It can be observed that the change of the output power $\Delta \mathrm{P}>0$ means a change of output voltage is in the right direction. If $\Delta \mathrm{P}<0$, it means the change of the output voltage is in the wrong direction. Therefore, the direction of the perturbation needs to be adjusted. 


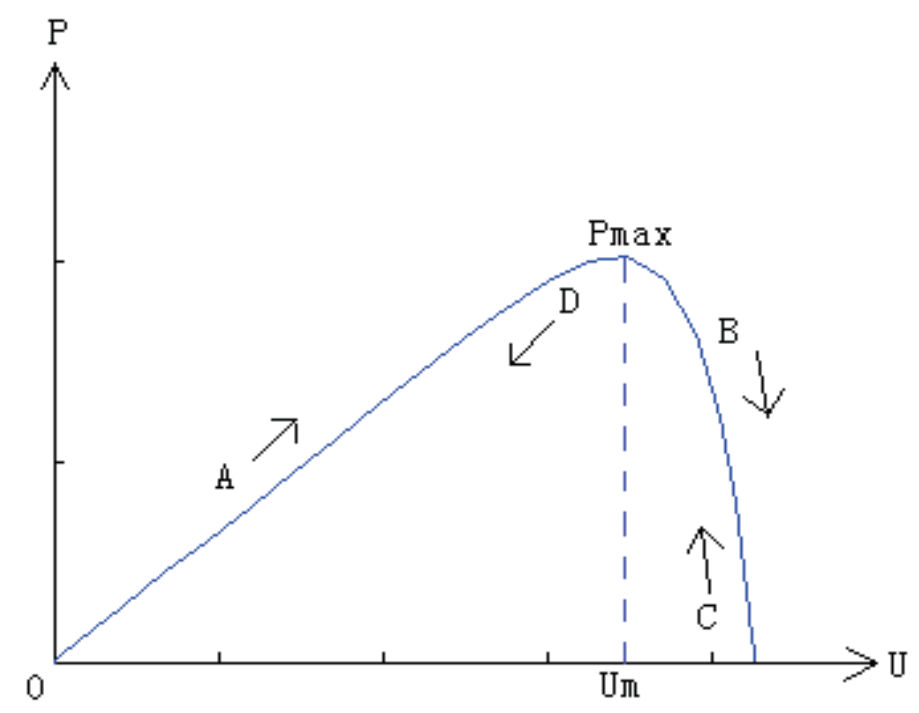

Figure 12: The Process of P\&O

Figure 12 shows the basic idea of perturbation and observation process. When the output voltage of solar cell is increasing the output power of the solar cell is also increasing, like situation A in Figure 12. So the voltage needs to be kept increasing to make output power nearer to $\mathrm{P}_{\max }$. The output voltage needs to be decreased to get a bigger output power, if the output voltage of the solar cell is increasing, and the output power is decreasing, like situation B. The voltage needs to be kept decreasing, if the power is increasing while the voltage is decreasing, like situation $\mathrm{C}$. The output voltage needs to be increased to get a bigger output power, when the voltage is decreasing. As a result, the output power of the solar cell is also decreasing, like situation D. Figure 13 shows the flowchart of the basic logical thinking of perturbation and observation. 


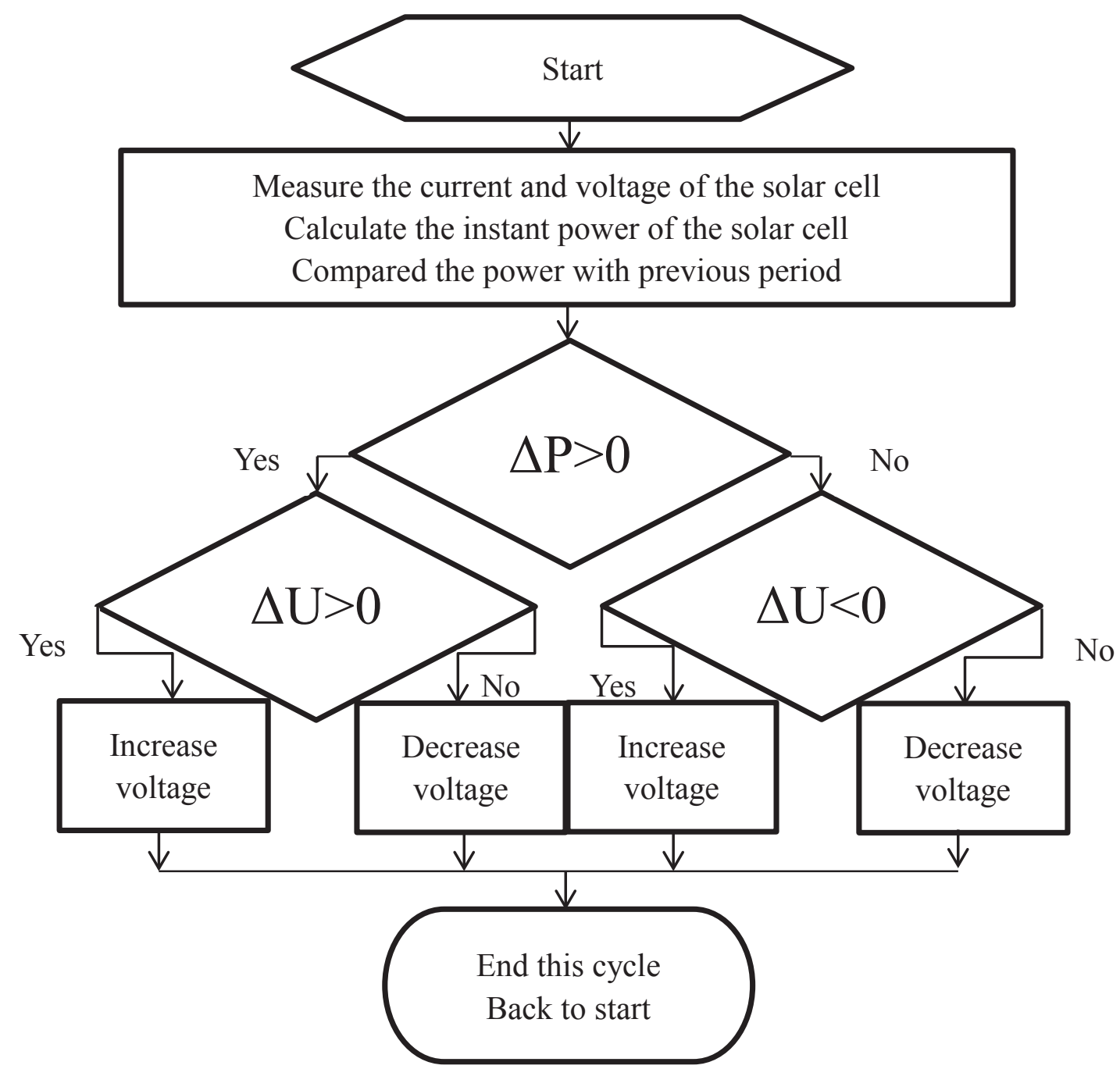

Figure 13: Flowchart of P\&O

The actual working condition of the solar cell will gradually approach the current maximum power point, and eventually work near the maximum power point. The solar cell will get to maximum power point very fast by using large step of $U$. The consequence of using a large step is when the working condition is near the maximum power point it will bounce forward and backward around the maximum power point, in other words, it isn't accurate enough. The result of using a small step of $U$ is exactly the opposite from the previous one. The result will be more accurate, but it will take more time for the solar cell to get near to the maximum power point. 
Error may occur in the $\mathrm{P} \& \mathrm{O}$ system, when solar radiation or temperature change sharply. Figure 14 shows what may happen if solar radiation intensity increases. We assume the system is running a normal cycle from A to B by decreasing the output voltage when the solar radiation is $400 \mathrm{~W} / \mathrm{m}^{2}$. After finishing this cycle, the system will realize that the perturbation direction is wrong by measuring a negative $\Delta \mathrm{P}$. If the solar radiation intensity suddenly increases to $1000 \mathrm{~W} / \mathrm{m}^{2}$ before the system finishes this cycle the solar cell will be working at $\mathrm{C}$, so the measurement result of $\Delta P$ of this cycle will be positive. In this case the system will think that the perturbation is in the right direction and keep the direction to $\mathrm{D}$, which is obviously wrong.

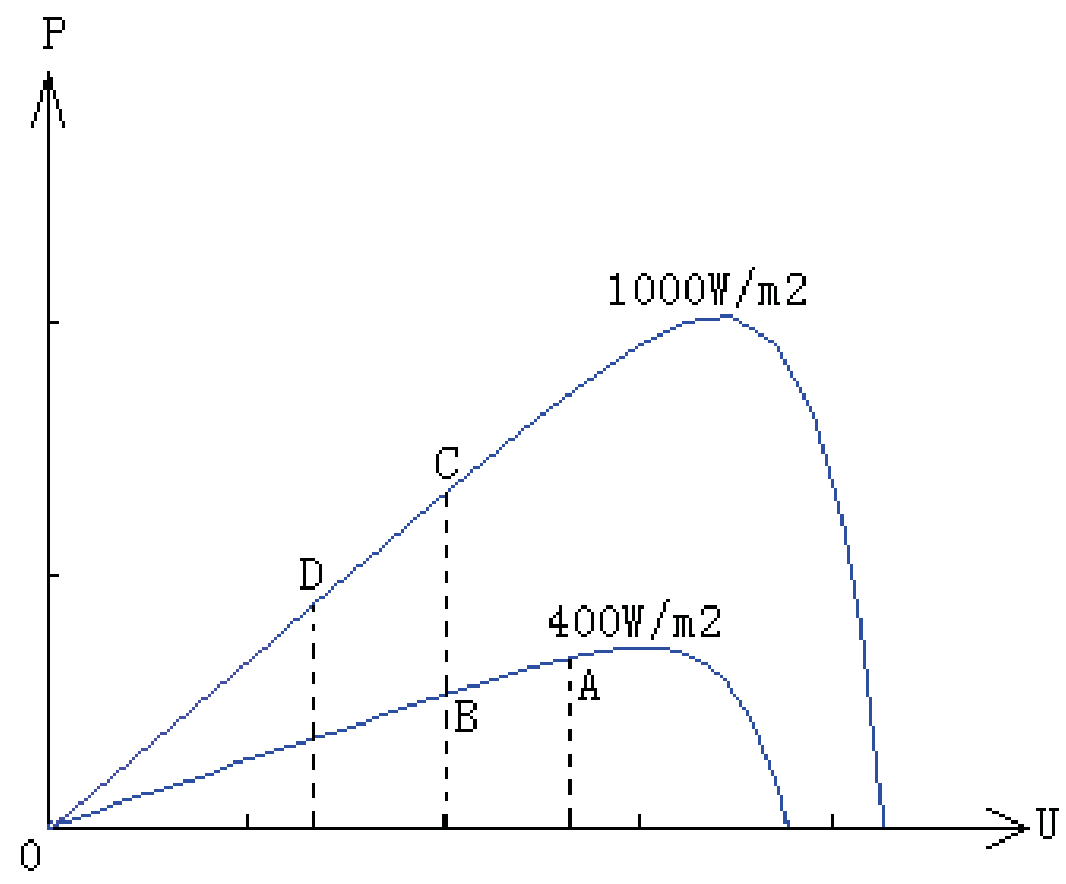

Figure 14: Error in P\&O System

Advantages of $\mathrm{P} \& \mathrm{O}$ :

1) Easy to control

2) Cheap 
Disadvantages of $\mathrm{P} \& \mathrm{O}$ :

1) The solar cell working near the maximum power point not exactly at the maximum power point causes power loss

2) Tracking speed and accuracy cannot be both reached

3) Error could occur under particular circumstances

\subsection{The Control Method of Maximum Power Point Tracking System}

Normally we use DC-DC converter to achieve the conformity of the MPPT behavior. Buck converter is been used in this report, which is showed in Figure 15.

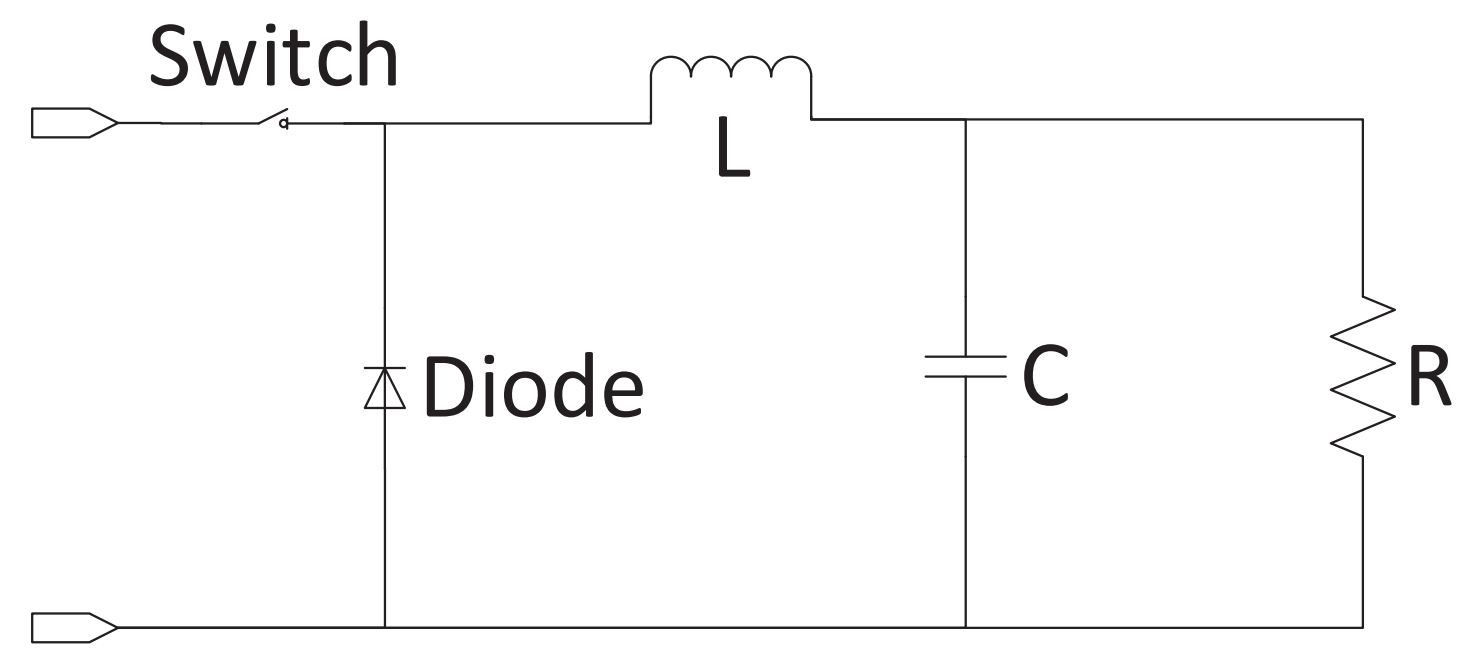

Figure 15: Buck Converter

The main idea of reaching the maximum power point of a linear system is to change the external resistance equal to internal resistance of the power source. In this case, the buck converter and the load which are connected to each other can be considered as one external resistance which is showed in figure 16. 


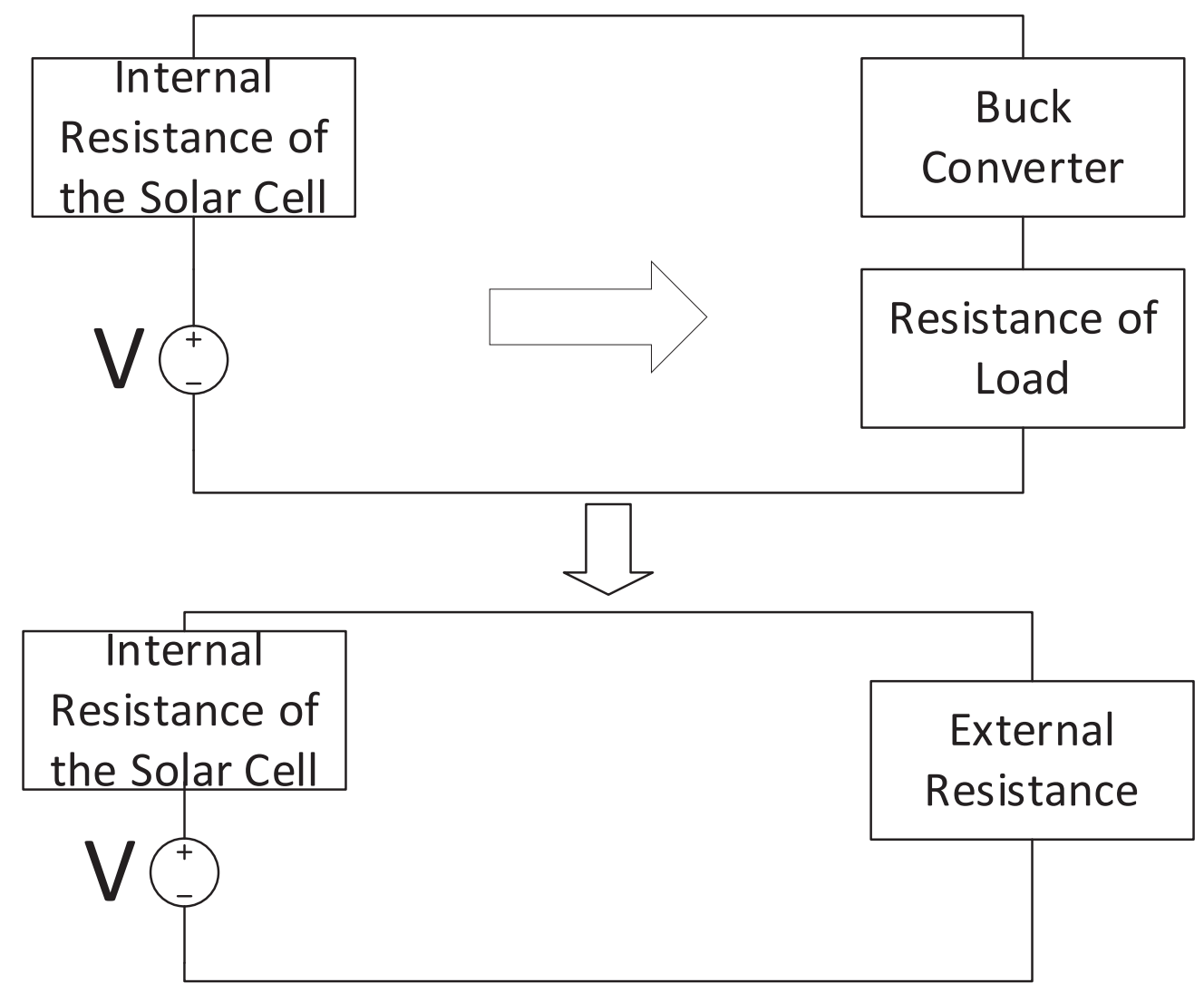

Figure 16: Equivalent Circuit

The relationship with the input voltage and the output voltage of the buck-converter is:

$$
V_{\text {in }}=\frac{V_{\text {out }}}{D}
$$

$\mathrm{D}$ is the duty ratio of the converter.

Because the output power is equal to its input power of an ideal converter, so the relationship between input current and the output current of the buck-converter is:

$$
I_{\text {in }}=I_{\text {out }} * \mathrm{D}
$$

So the equivalent resistance can be solved:

$$
R_{\text {eq }}=\frac{V_{\text {in }}}{I_{\text {in }}}=\frac{V_{\text {out }} / D}{I_{\text {out }} * D}=\frac{V_{\text {out }}}{I_{\text {out }}} / D^{2}=R_{\text {load }} / D^{2}
$$


From the equation (15), it is can be seen that the value of the equivalent resistance is inversely proportional to $D^{2}$, which means the value of the external resistance can be easily changed by changing the duty ratio of the converter.

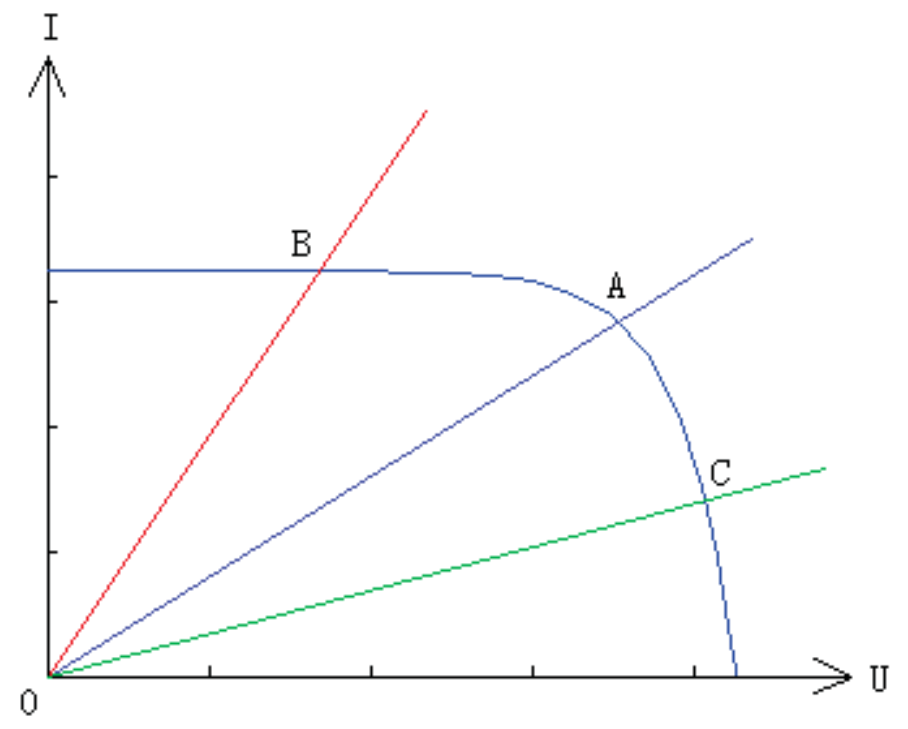

Figure 17: The I-V Characteristic of Solar and External Resistance

The curve in figure 17 is I-V output characteristic of the solar cell. The straight lines are I-V characteristics of the external resistance in three different conditions. The intersection of the curve and straight lines are three different working conditions of the solar cell. As we can see the line in the middle is meeting the curve at maximum power point (A), which means the solar cell is working at maximum power condition, and no further MPPT is required. The upper line is meeting the curve at point $\mathrm{B}$, in this case the system needs to increase the value of external resistance to reach the maximum power point by reducing the duty ratio of the converter. The duty ratio of the converter needs to be increased for the lower line which is meeting the curve at point $\mathrm{C}$. 


\subsection{The Simulation Model of Maximum Power Point Tracking System}

The simulation model of the MPPT system is showed in Figure 18. $U_{\text {in }}$ and $I_{\text {in }}$ are the voltage and current measured from the export terminal of the solar cell. Then power for this cycle is calculated by using current and voltage.
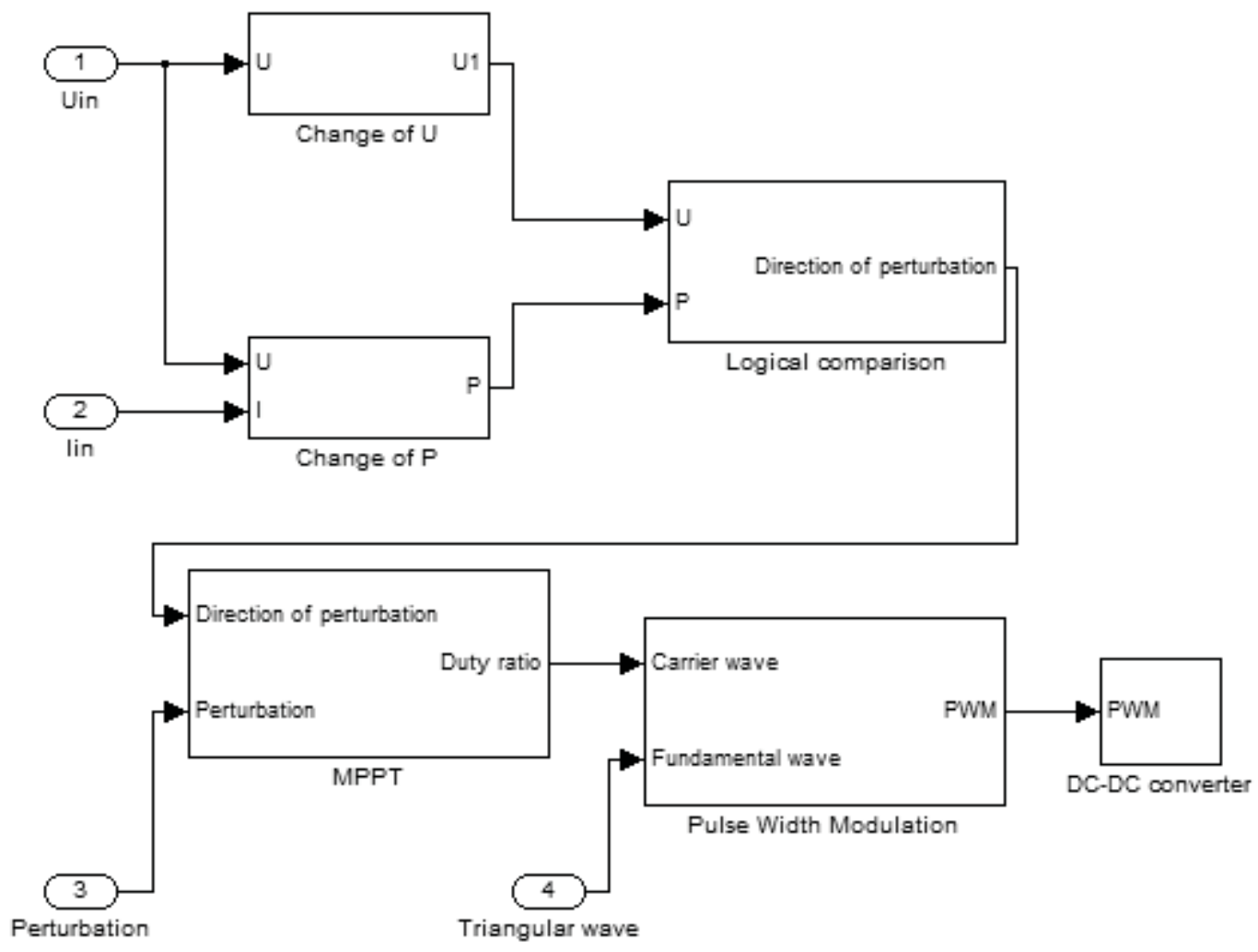

Figure 18: Simulation Model of MPPT system

In order to determine whether to increase or decrease the duty ratio of the converter, the changes of voltage and power are analyzed. As a result, a new PWM signal to control the converter by combining the duty ratio and a fundamental triangular wave is obtained. 


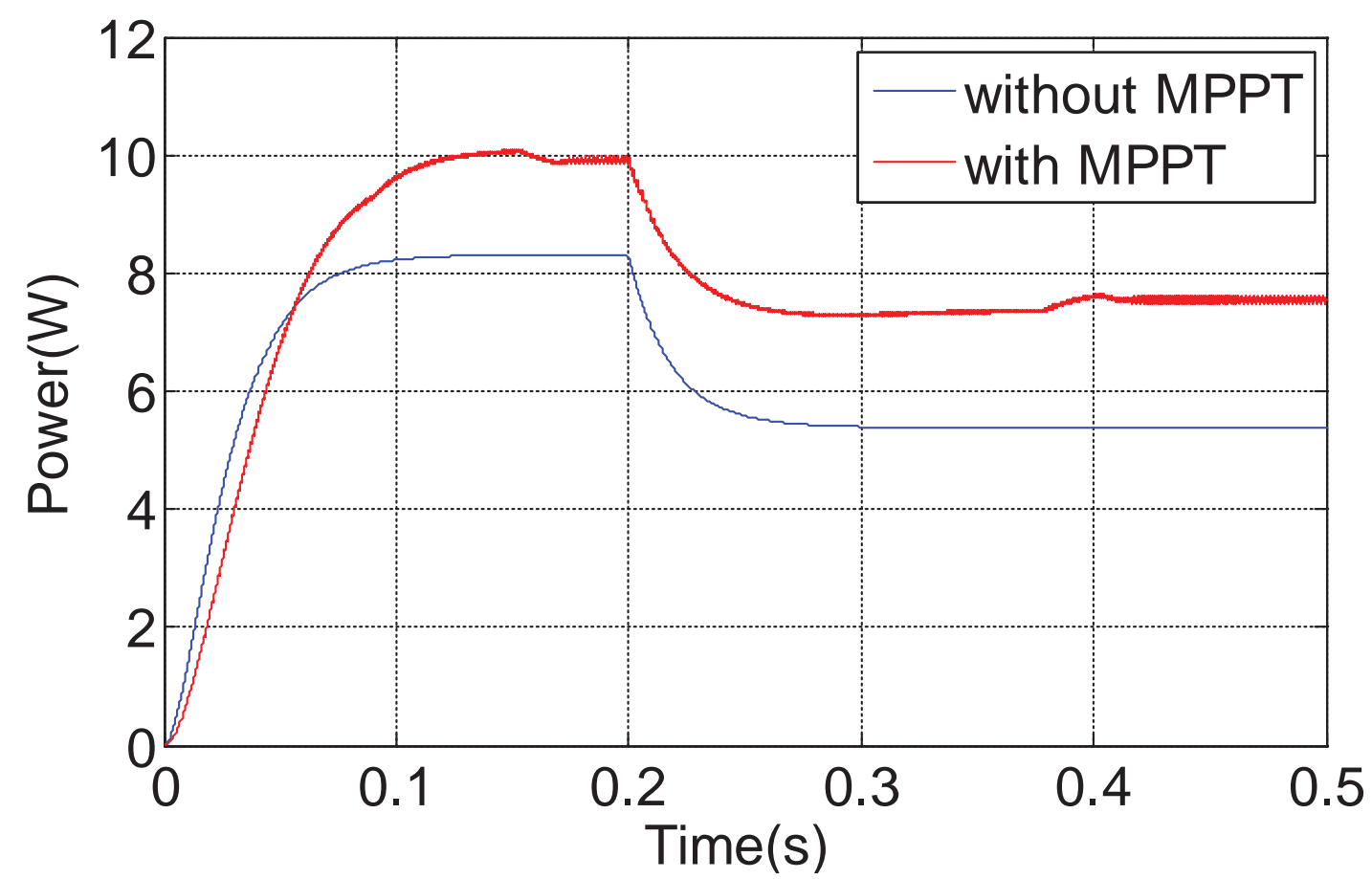

Figure 19: Simulation Result of Solar System With and Without MPPT

Figure 19 shows the simulation result of the system. These two simulations are both for the same solar cell as in Chapter 3.6. The difference is that the first one is without MPPT, and the second one is with MPPT. The temperature of the simulation is $25^{\circ} \mathrm{C}$. The solar radiation is $1000 \mathrm{~W} / \mathrm{m}^{2}$ at the beginning and then drops to $700 \mathrm{~W} / \mathrm{m}^{2}$ at a particular moment. As it can be seen, the output power of the system with MPPT is on average 30\% large than the system without MPPT. 


\section{The Simulation of Household Solar Power System with Maximum}

\section{Power Point Tracking}

\subsection{The Simulation Model of the System}

Figure 20 shows the simulation model of a household solar power system. During the daytime, the solar panel module is generating power to supply the load and charge the battery. While it is working, the MPPT module uses the PWM signal to control the equivalent resistance of the external system to reach the maximum power point of the solar panel by measuring the output current and voltage of the solar panel. During the night time, the solar panel and MPPT system is shut down, and the load is consuming the power that is stored in the battery.

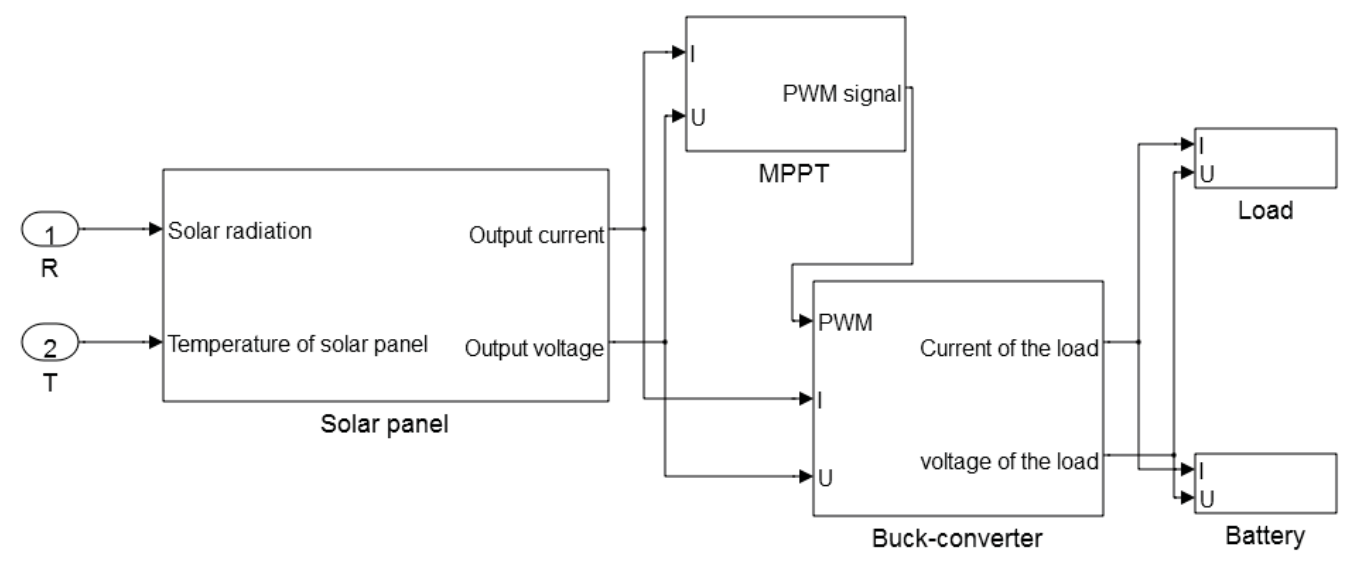

Figure 20: The Simulation Model of Household Solar Power System 


\subsection{The Parameter Settings of the Simulation}

The southwest of the U.S.A is a good place to set up a solar system which is shown in Figure 21. Assuming the household solar system is set up in an urban area of Houston (Texas). The average solar radiation level of Houston is $5.5 \mathrm{kWh} / \mathrm{m}^{2} / \mathrm{day}$.

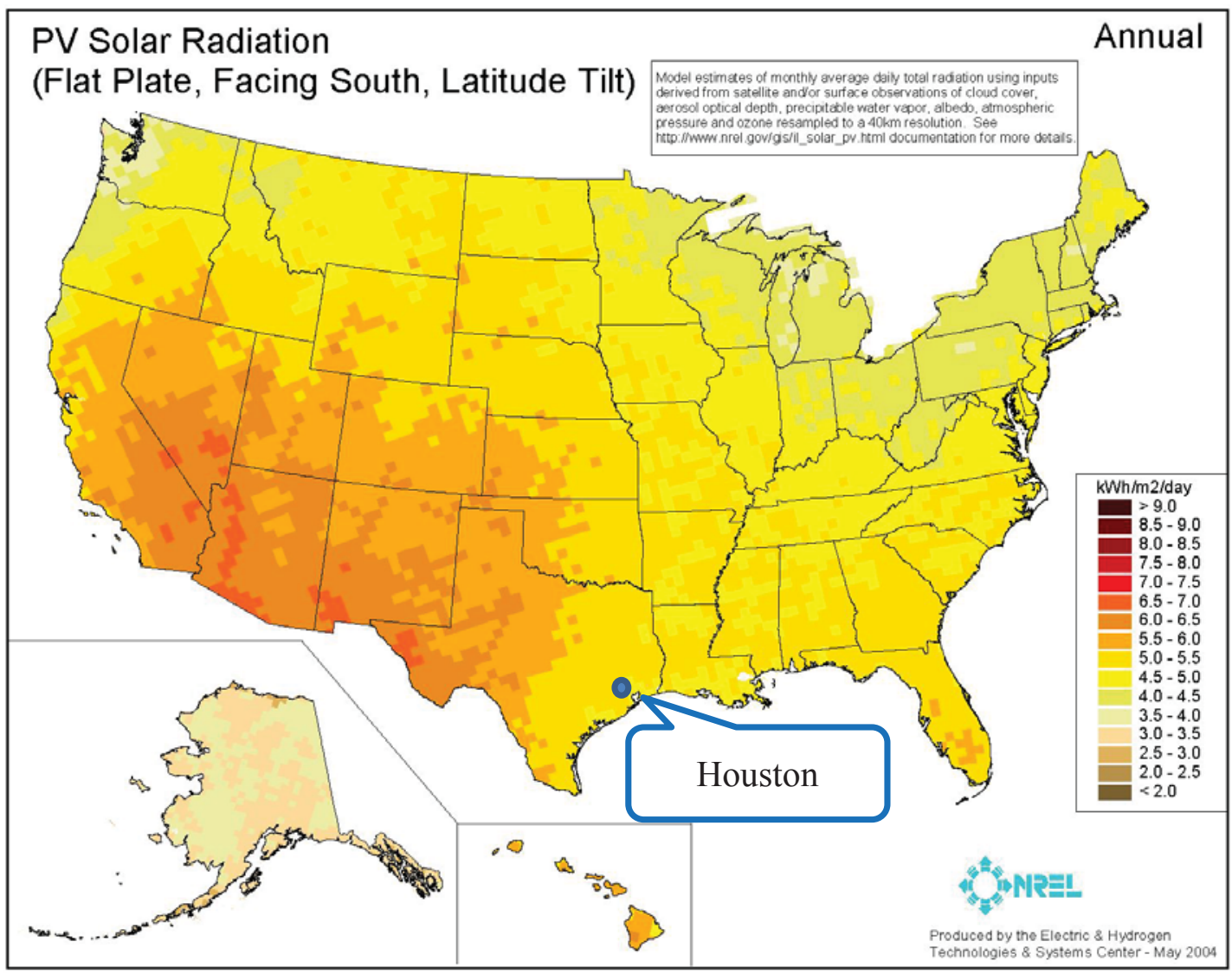

Figure 21: The Average Solar Radiation Level in May 2004, USA [11]

Assuming the day time is twelve hours, and during day time the trend of the solar radiation curve is similar to a positive half cycle of a sine function. The peak value of the solar radiation can be solved:

$$
5500=\int_{0}^{12}\left(\beta * \sin \left(\frac{12}{\pi} h\right)\right) d h
$$

After solving the equation (16), the average peak value of solar radiation in Houston is $1208.95 \mathrm{~W} / \mathrm{m}^{2}$. In this report, the peak value of solar radiation is been set to 
$1200 \mathrm{~W} / \mathrm{m}^{2}$.

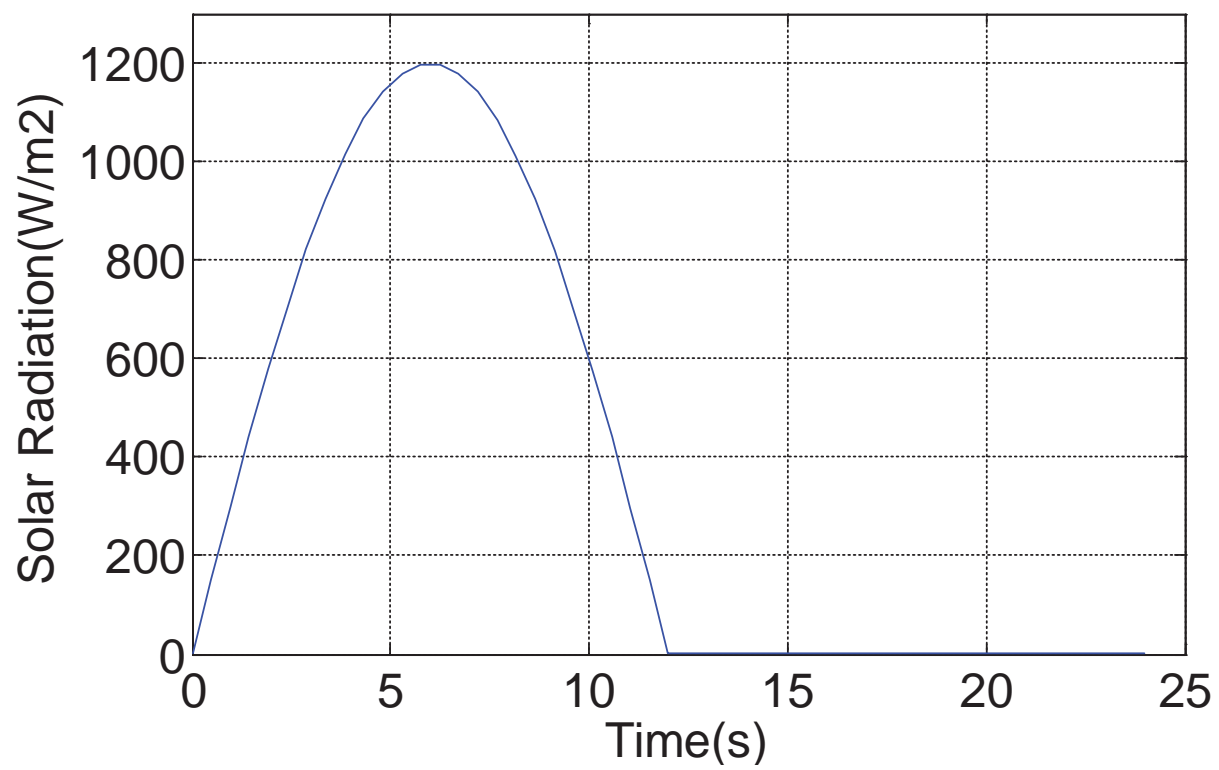

Figure 22: The Solar Radiation Curve in Houston for Twenty-four Hours

Figure 22 shows the solar radiation level of one day. In Matlab, the simulation runs for twenty-four seconds, and one second stands for one hour in real life. The number 0 stands for six o'clock in the morning. When the sun rises up, the radiation level starts increasing. When the simulation reaches six seconds, which means twelve o'clock noon, the radiation reaches its peak value of the day, after that the solar radiation level begin to decrease. When the simulation reaches twelve seconds, which means six o'clock in the afternoon, the solar radiation level disappeared. And there will be no solar radiation for twelve hours until the next day. 


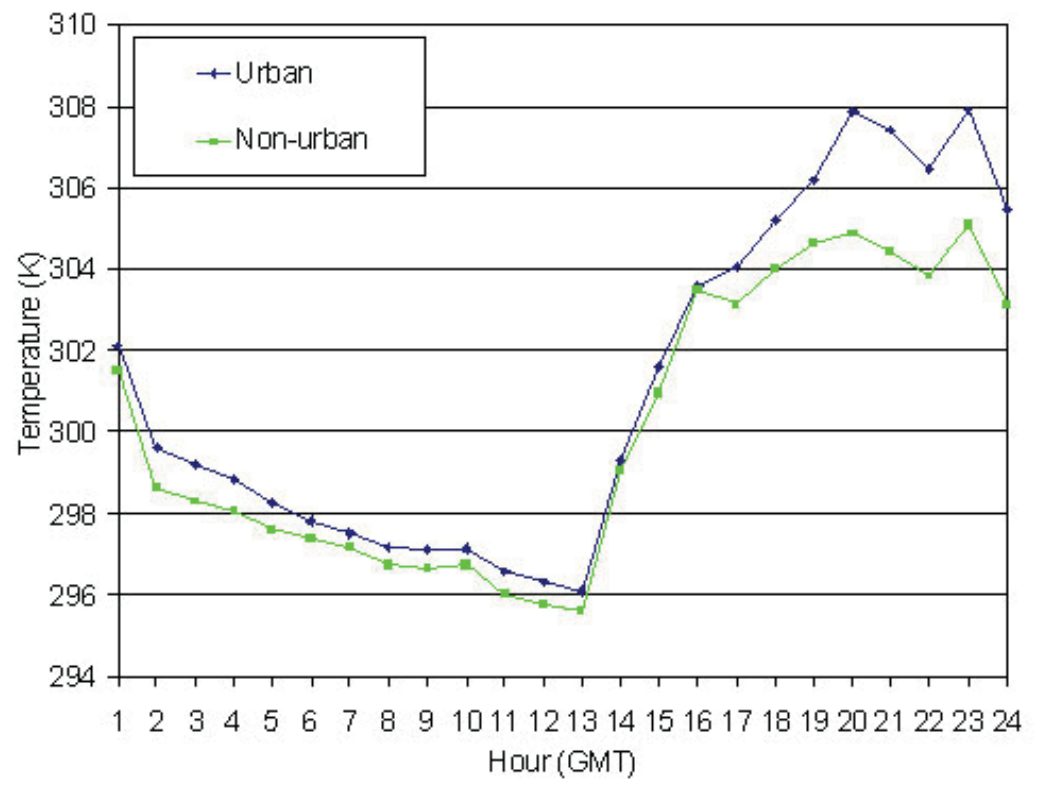

Figure 23: Surface Temperature of Houston Urban and Outlying Non-Urban Areas in August 22, $2002[12]$

The temperature of solar cell is different from the normal weather temperature which is air temperature. The surface temperature which shown in Figure 23 is similar to the temperature of solar cell, and it is used in the solar cell model.

The lowest surface temperature of Houston urban area in one day is $269 \mathrm{~K}\left(23^{\circ} \mathrm{C}\right)$. The highest surface temperature of Houston urban area in one day is $308 \mathrm{~K}\left(35^{\circ} \mathrm{C}\right)$. Assuming the trend of the temperature curve is similar to one whole cycle of a sine function. The peak value of the sine function is 35 . And the valley value of the sine function is 23 . 


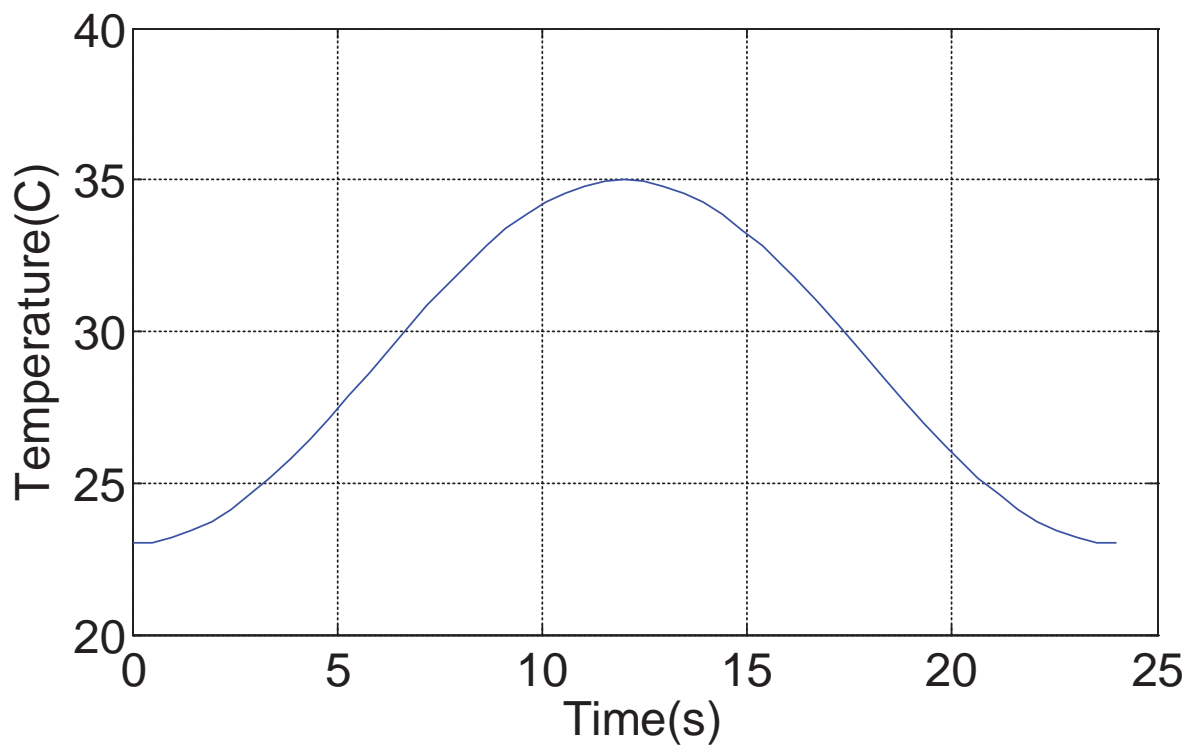

Figure 24: Solar Cell Temperature for Twenty-four Hours

Figure 24 shows the temperature of solar panel for 24 hours. The temperature starts to increase from $23^{\circ} \mathrm{C}$ to $35^{\circ} \mathrm{C}$ after the sun rises, and decrease from $35^{\circ} \mathrm{C}$ to $23^{\circ} \mathrm{C}$ after the sun set.

STP180S-24/Ad model of solar cell is used in the simulation. The technical parameters of this kind of solar cell provided by the supplier are: $I_{s c}=5.43 \mathrm{~A}, U_{o c}=45 \mathrm{~V}, I_{m}=$ $5.09 \mathrm{~A}, U_{m}=36.4 \mathrm{~V}$. The maximum power of a single solar cell is $185.276 \mathrm{~W}$, which is obviously too small for a household circuit system. After connecting five solar cells in parallel, and connecting five of these solar cells which are already in parallel in series, a big solar panel which made by 25 solar cells ( 5 by 5 ) will be obtained. The technical parameters of this new solar panel are: $I_{s c}=27.15 \mathrm{~A}, U_{o c}=225 \mathrm{~V}, I_{m}=$ $25.45 \mathrm{~A}, U_{m}=182 \mathrm{~V}$. The maximum power of the solar panel is $4631.9 \mathrm{~W}$. The simulation model of battery is the battery module in SimPowerSystem. The nominal voltage of the battery module is $24 \mathrm{~V}$. The rated capacity of the battery module is $360 \mathrm{Ah}$. And the initial SOC is $30 \%$. 


Nominal Voltage (W)
24
Rated Capacity (Sh)
0.1
Initial State-Of-Charge $(\%)$
30

Figure 25: Basic Parameters of the Battery

Figure 25 shows the basic parameters of the battery that is connected to the load in parallel. Assume that after overnight working the state of charge of the battery drop to $30 \%$. The reason that the rated capacity of the battery is only 0.1 is the simulation runs in seconds, but 1 second stands for 1 hour in real life. So the unit of rated capacity here is not Ampere-hour, but Ampere-second. 0.1 need to be multiplied by 3600 second/hour to obtain the real capacity. In this case the rated capacity of the battery is $360 \mathrm{Ah}$.

\subsection{The Simulation Results}

The output power of the household solar system is shown in Figure 26. As it can be seen, the solar panel starts to generate power when the simulation started. When the simulation reaches six seconds, the peak value of the solar panel output power has been reached, which is $5568 \mathrm{~W}$. After that, the output power of the solar panel starts to decrease, and becomes zero when the simulation reaches twelve seconds. 


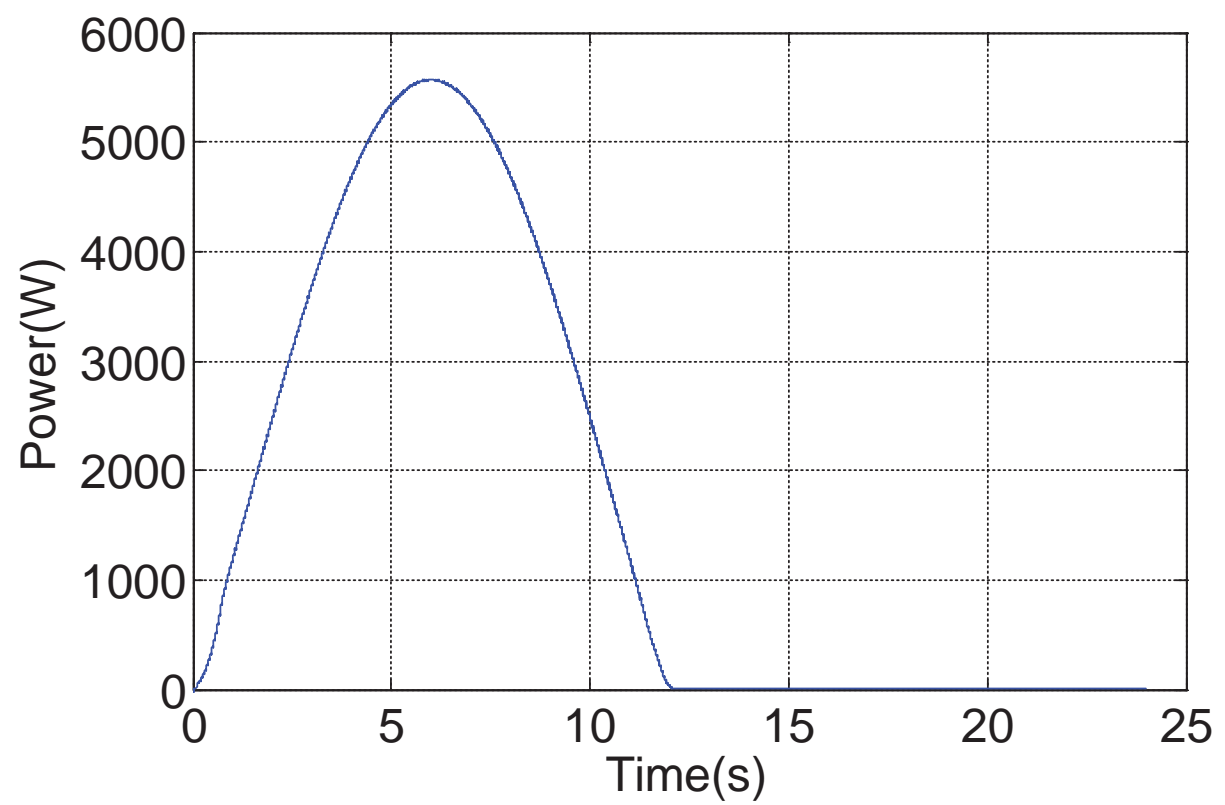

Figure 26: Output Power of Solar Panel

As it can be seen, the output power curve from one second to twelve seconds is concave up. The curve from zero second to one second is concave down. That is because after the simulation started the MPPT system took about one second to reach the maximum power point. After the first second, the MPPT system reached the maximum power point and kept the system working near the maximum power point.

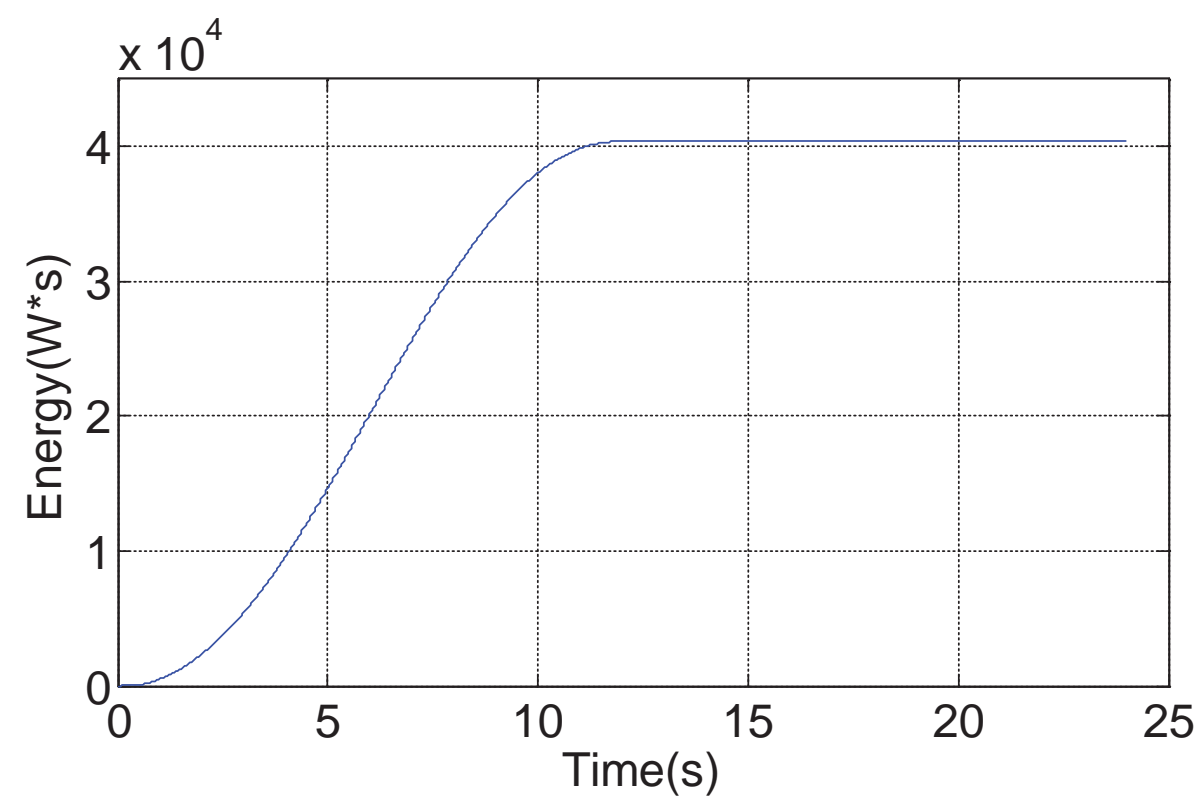

Figure 27: Output Energy of Solar Panel 
After integrating the output power of the solar panel, the Output Energy of solar panel can be obtained which is shown in Figure 26. In the simulation, the solar panel generates $40392 W * S$ energy for 24 seconds. In real life, the same process will last for 24 hours, which means the solar panel will generate $40392 W * h$ energy for one day.

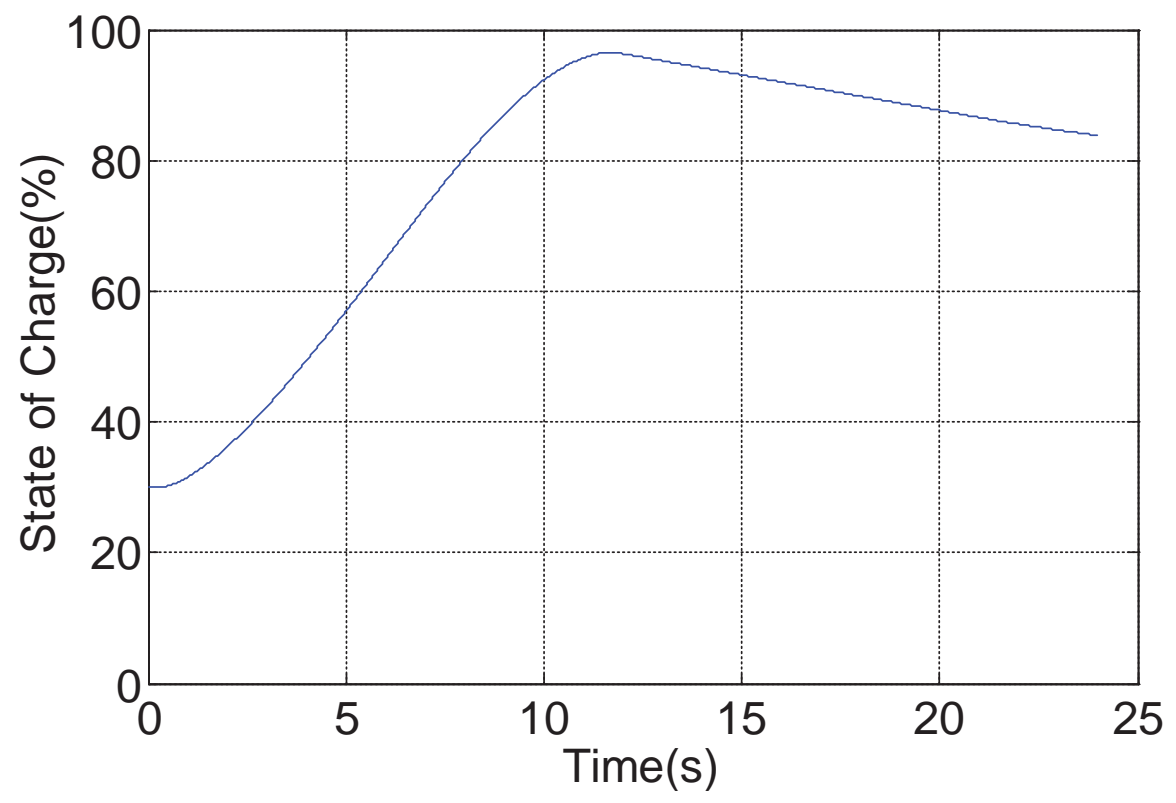

Figure 28: Battery State of Charge

The SOC of the battery is shown in Figure 27. It can be seen that in the first twelve seconds of the simulation (daytime) the SOC of the battery increases from $30 \%$ to $97 \%$. In the second twelve seconds of the simulation (night time), the SOC of the battery decreases from $97 \%$ to $84 \%$. After analysis the data in Figure 28, the following characteristics can be figured out:

1) At least two sunny days are needed to recharge the battery from $0 \%$ to $100 \%$.

2) If the battery is fully charged, it can supply power to the consumers for 92.31 hours without recharging (almost four days with no sun). 


\section{The Economic Effects of the Solar System}

The price of the whole household solar system is related to the output power of the system. Normally the price of high quality household solar system is $0.8-1.8 \$ / W$. In this report the average price is taken, which is $1.3 \$ / \mathrm{W}$. The output power of the solar system in the report is $4631.9 \mathrm{~W}$, which means the price of the whole solar system is $1.3 \$ / W * 4631.9 W=6021.47 \$$.

The price of residential electric power was $0.1212 \$$ per kilowatt-hour in Texas during June 2014. The system generates $40392 W * h$ of energy for one sunny day, which means after the system been installed it will make $0.1212 \$ / k W h * 40.392 \mathrm{kWh}=$ $4.896 \$$ profit for one sunny day. After 1230 sunny days (3.37 years) of operation, the system achieves a balance of income and expenditure.

\begin{tabular}{|c|c|c|c|c|}
\hline (days) & Sunny Clear & $\begin{array}{c}\text { Partly Cloudy } \\
\text { Mostly Sunny }\end{array}$ & $\begin{array}{c}\text { Mostly Cloudy } \\
\text { Partly Sunny }\end{array}$ & $\begin{array}{c}\text { Rain, Snow or } \\
\text { Thunderstorms }\end{array}$ \\
\hline January & 1 & 6 & 11 & 13 \\
\hline February & 1 & 9 & 8 & 10 \\
\hline March & 3 & 13 & 10 & 5 \\
\hline April & 0 & 8 & 11 & 11 \\
\hline May & 0 & 12 & 13 & 6 \\
\hline June & 0 & 17 & 5 & 8 \\
\hline July & 0 & 16 & 3 & 12 \\
\hline August & 0 & 22 & 1 & 8 \\
\hline September & 1 & 11 & 6 & 12 \\
\hline October & 4 & 12 & 2 & 13 \\
\hline November & 1 & 10 & 10 & 9 \\
\hline December & 1 & 7 & 17 & 6 \\
\hline Total & 12 & 143 & 97 & 113 \\
\hline
\end{tabular}

Table 1: Weather history of Houston in 2013 [13]

Table 1 shows the weather history of Houston in 2013. We will assume the following:

1) The solar panel will generate $100 \%$ of rated energy in sunny clear days. 
2) The solar panel will generate $70 \%$ of rated energy in partly cloudy mostly sunny days.

3) The solar panel will generate $30 \%$ of rated energy in mostly cloudy partly sunny days.

4) The solar panel generates no energy at all in rain, snow or thunderstorms days.

In this case, the solar system makes $4.896 \$ *(12 * 100 \%+143 * 70 \%+97 *$ $30 \%+113 * 0 \%)=714.745 \$$ profit per year. After 8.42 years operation, the system achieves a balance of income and expenditure. 


\section{Conclusions}

This report presented the sizing and simulation of a household solar power system. By analyzing and simplifying the mathematical Model of solar cell, the simulation model of solar cell can be obtained. P\&O has proved to be a viable option for MPPT.

The simulation shows that the solar system with MPPT can reach maximum power in a short time, and generates about 30\% more power than the solar system without MPPT system. The most important factor of a solar power system is solar radiation level, in other words, weather conditions. The system may loss large number of energy if the weather conditions are not good. In the final simulation, the household solar system generates $40.392 \mathrm{kWh}$ per sunny day. 3.37 years are need for the system to achieve a balance of income and expenditure if it is all sunny days. 8.42 years are need for the system to achieve a balance of income and expenditure when weather conditions are considered. It is almost 2.5 times longer than the previous one.

In this report, the simulation runs for twenty-four seconds to represent a whole sunny day. In further discussion, the simulation time can be changed to seventy-two seconds to represent three days. Also change the radiation level for each day and see how the system goes simulate three days in a row. 


\section{References}

[1] M. A. S. Masoum, H. Dehbonei and E. F. Fuchs, "Theoretical and experimental analyses of photovoltaic systems with voltage- and current-based maximum power-point tracking", IEEE Trans. Energy Convers., vol. 17, no. 4, pp. 514-522, 2002 [2] N. Femia , G. Petrone , G. Spagnuolo and M. Vitelli, "Optimization of perturb and observe maximum power point tracking method", IEEE Trans. Power Electron., vol. 20, no. 4, pp. 963-973, 2005

[3] D. Sera, T. Kerekes, R. Teodorescu and F. Blaabjerg, "Improved MPPT method for rapidly changing environmental conditions", Proc. IEEE ISIE, pp. 1420-1425, 2006 [4] T. Esram and P. L. Chapman, "Comparison of photovoltaic array maximum power point tracking techniques", IEEE Trans. Energy Convers., vol. 22, no. 2, pp. 439-449, 2007

[5] N. Mutoh, M. Ohno and T. Inoue, "A method for MPPT control while searching for parameters corresponding to weather conditions for PV generation systems", IEEE Trans. Ind. Electron., vol. 53, no. 4, pp. 1055-1065, 2006

[6] N. Femia , D. Granozio , G. Petrone , G. Spagnuolo and M. Vitelli, "Predictive \& adaptive MPPT perturb and observe method", IEEE Trans. Aerosp. Electron. Syst., vol. 43, no. 3, pp. 934-950, 2007

[7] Leedy, A.W., Garcia, K.E., "Approximation of P-V characteristic curves for use in maximum power point tracking algorithms", System Theory (SSST), 2013 45th Southeastern Symposium on, pp. 88-93, 2013

[8]Available:http:/www.suketenergy.com/products/solar-home-lighting-system/\#

[9] Available: http://en.wikipedia.org/wiki/Solar_power_in_Massachusetts [10] Dong Jie, Zhang Chun-jiang, Li Yan-bang, "Comparison of Duty Ratio Perturbation \& 
Observation and Reference Voltage Perturbation \& Observation Methods Applied in MPPT", The 7th International Power Electronics and Motion Control Conference (IPEMC2012)

[11] Available: http://en.wikipedia.org/wiki/Solar_power_in_Texas [12]Available:http://www.nasa.gov/centers/goddard/news/topstory/2004/0113landair_p rt.htm

[13]Available:http://www.wunderground.com/history/airport/KHOU/2013/1/1/Monthl yHistory.html?req_city $=$ NA\&req_state $=$ NA\&req_statename $=$ NA 


\section{Appendices}

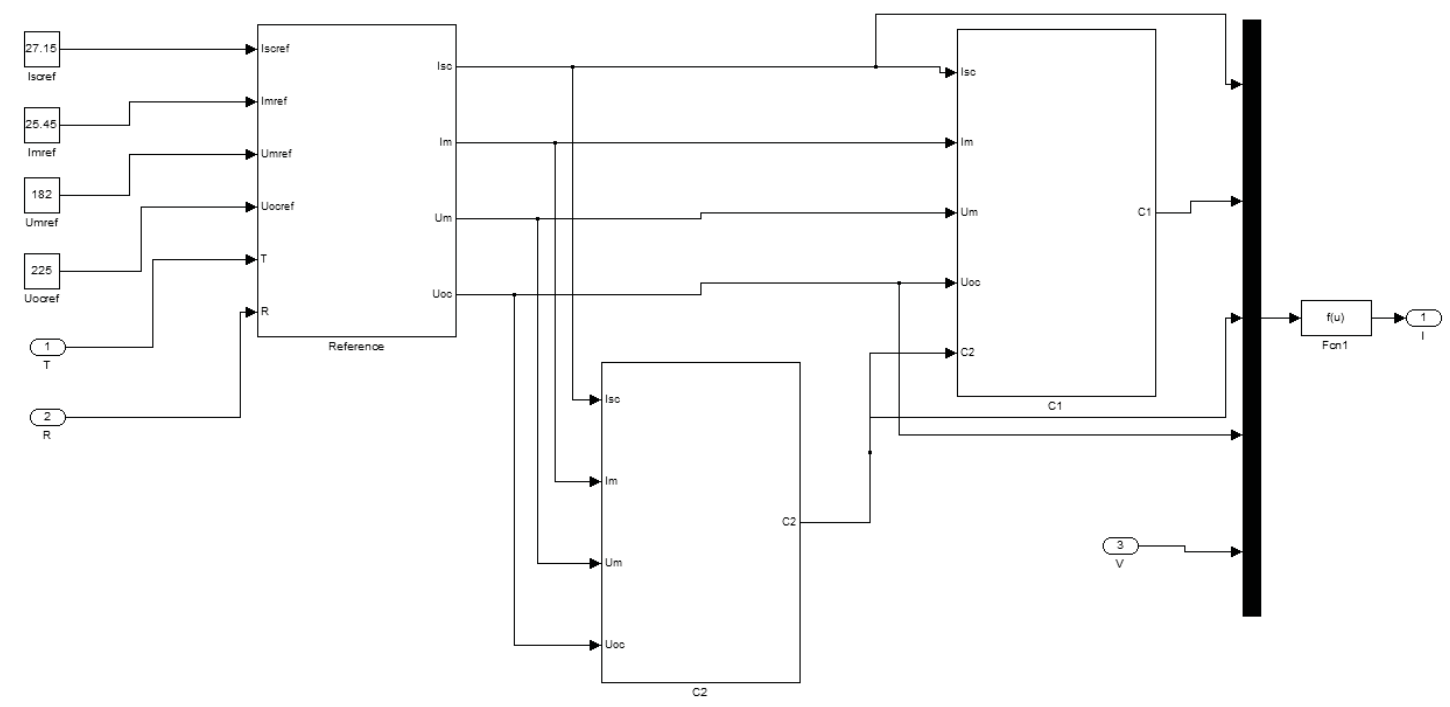

Figure 29: Model of Solar Panel

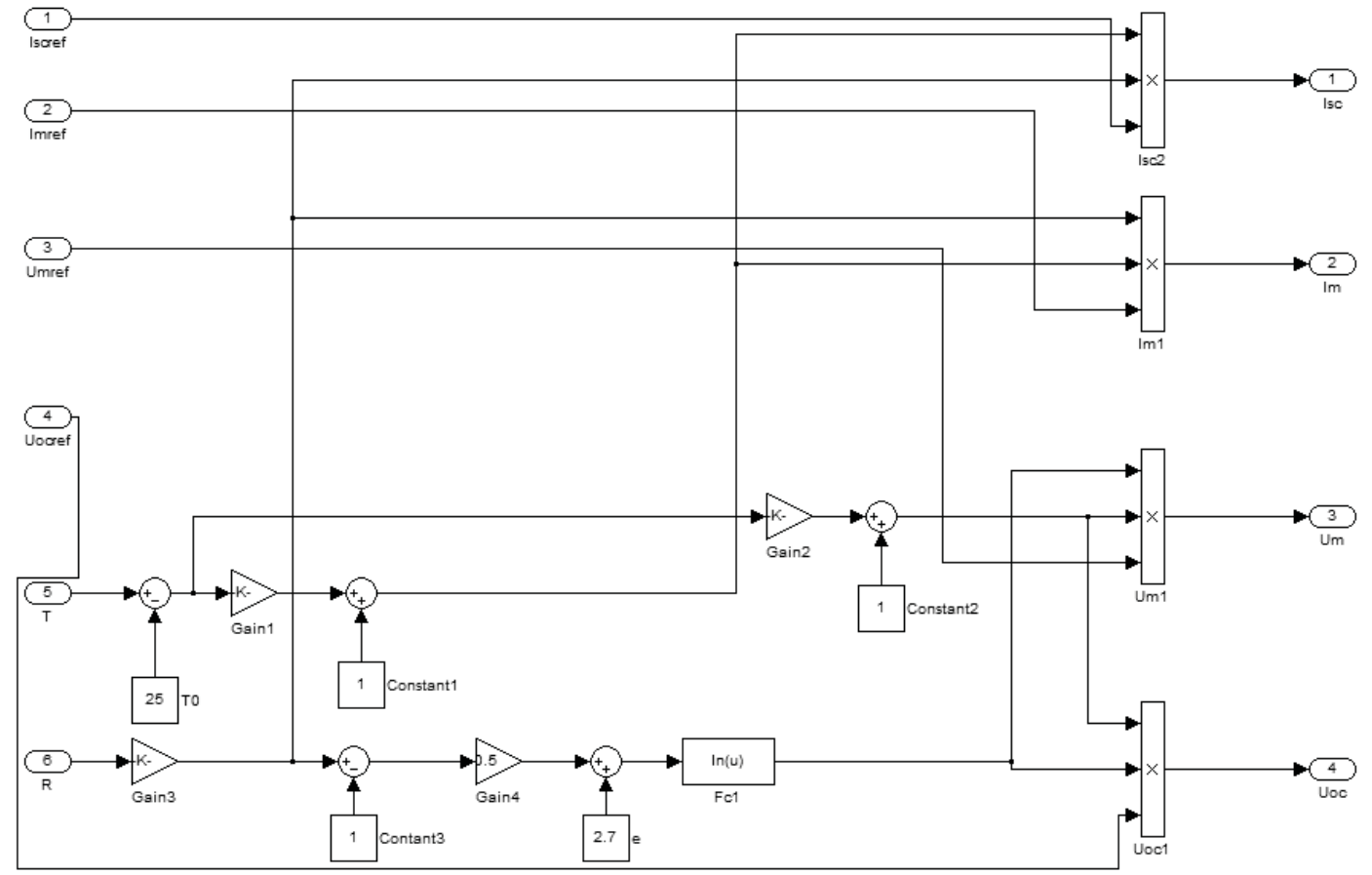

Figure 30: Model of Module Reference in Solar Panel 


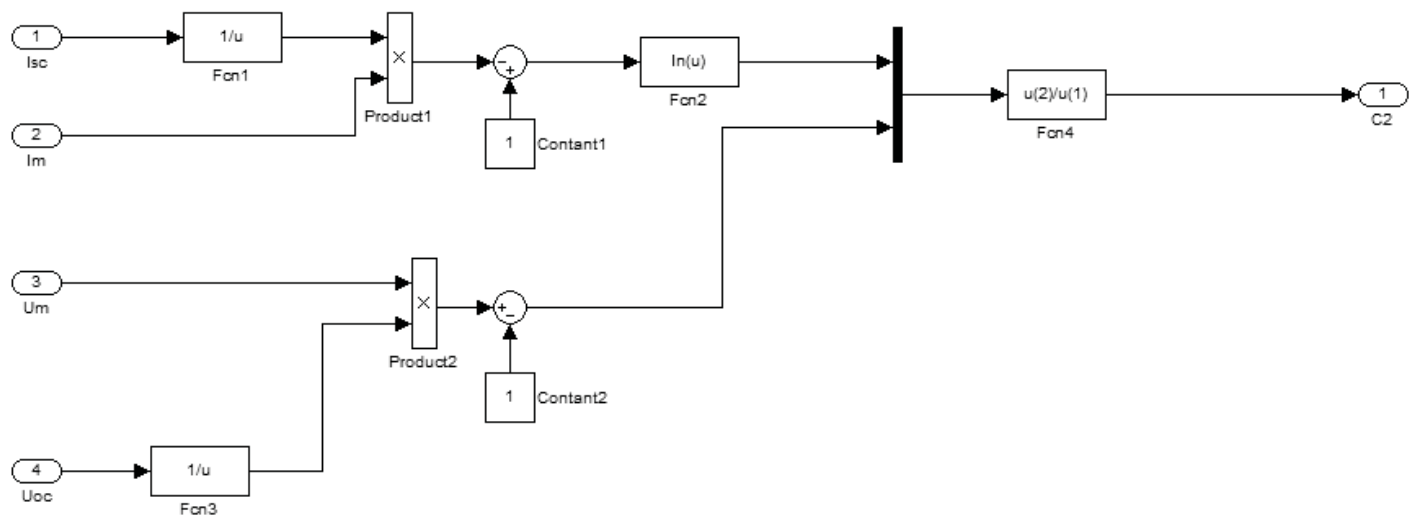

Figure 31: Model of Module C2 in Solar Panel

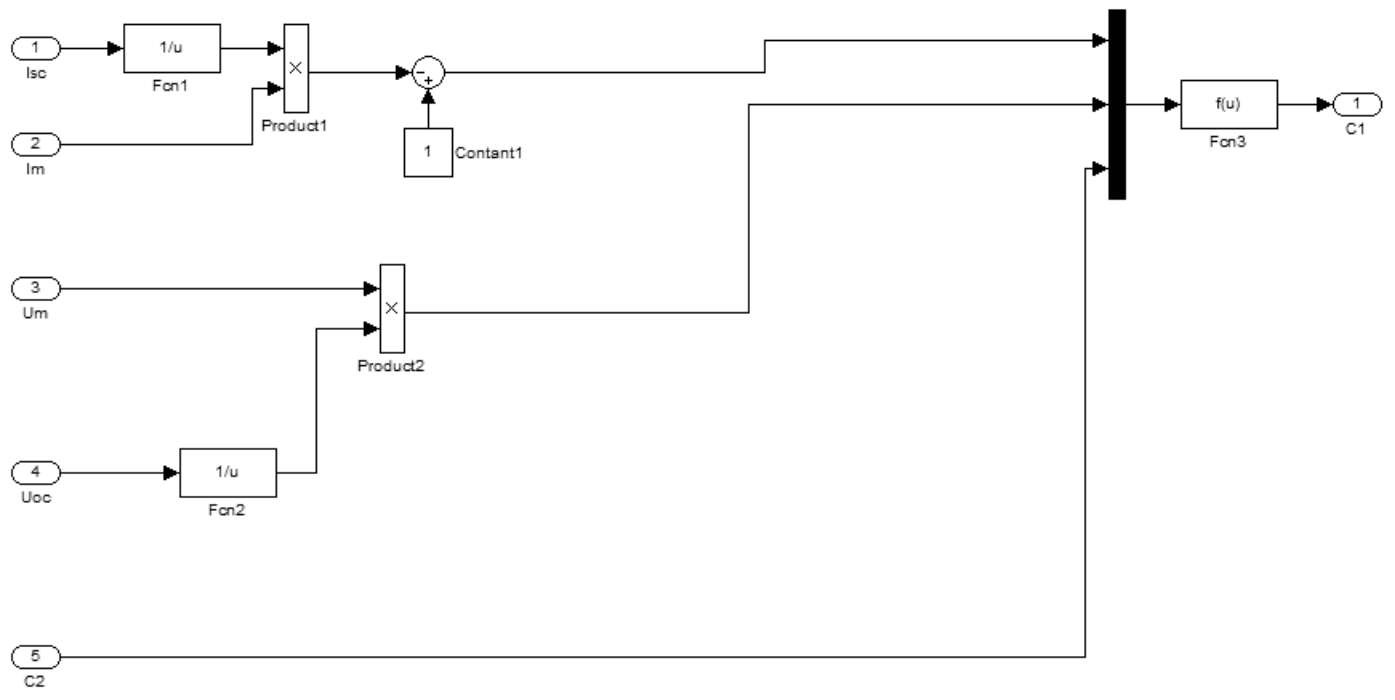

Figure 32: Model of Module C1 in Solar Panel

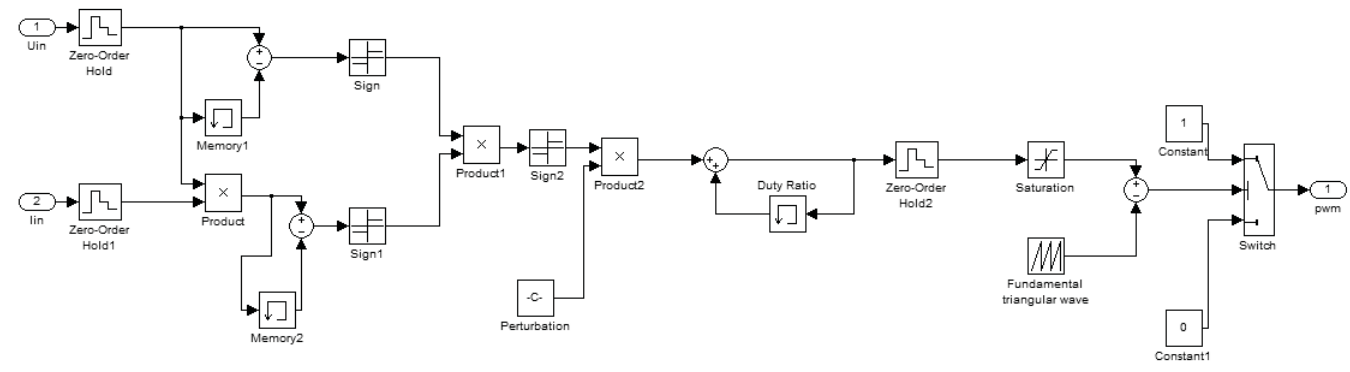

Figure 33: Model of Module MPPT System 


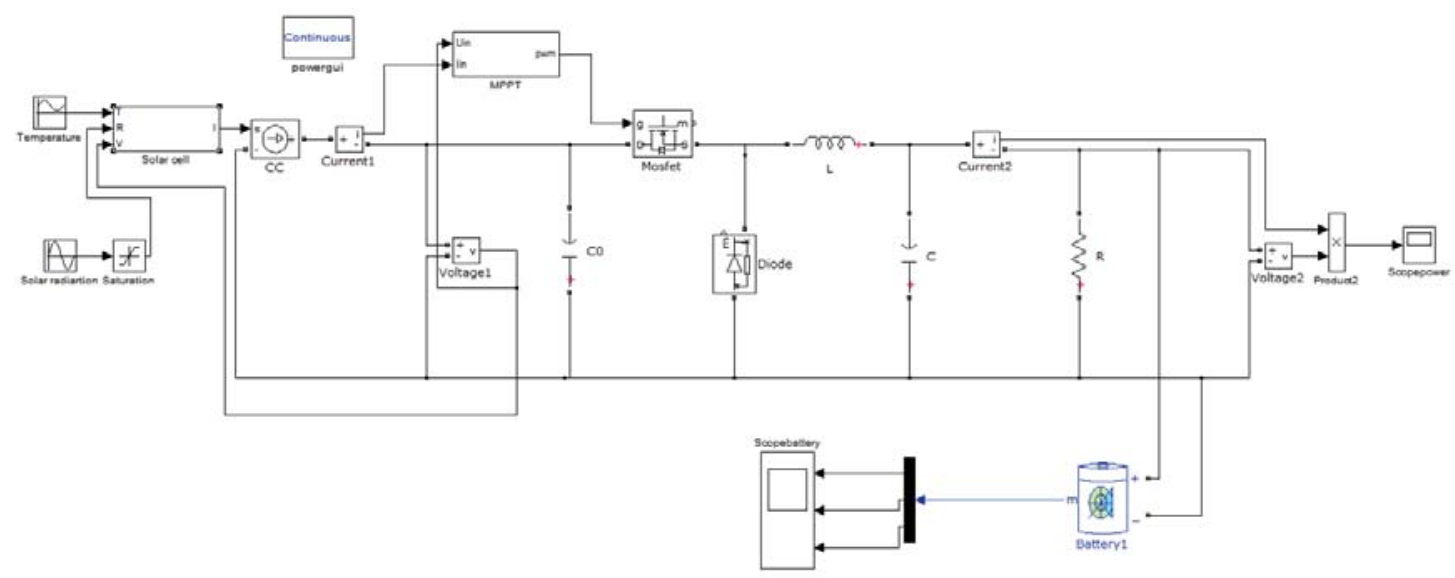

Figure 34: Model of Household Solar Power System with Maximum Power Point Tracking

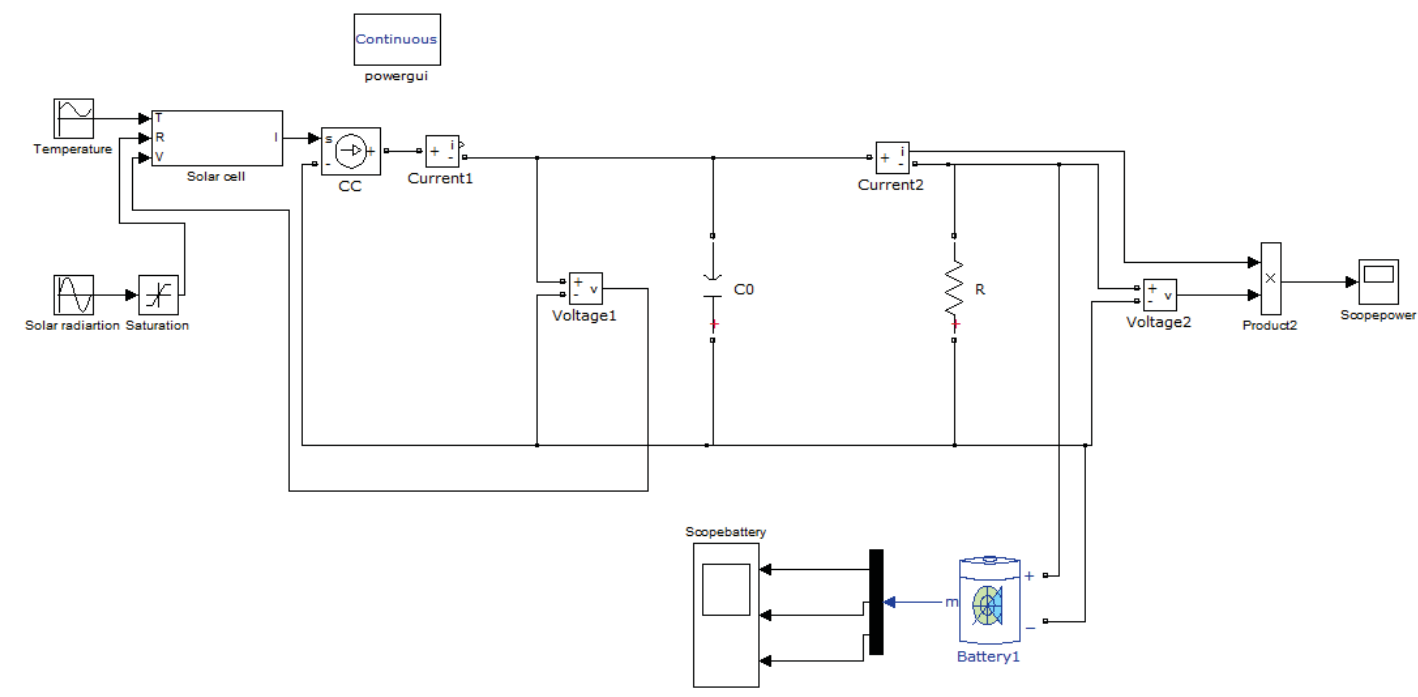

Figure 35: Model of Household Solar Power System without Maximum Power Point Tracking 